\title{
Subalpine Forest and Treeline Ecotone under the Influence of Disturbances: A Review
}

\author{
Friedrich-Karl Holtmeier1, Gabriele Broll² \\ ${ }^{1}$ Institute of Landscape Ecology, University of Münster, Münster, Germany \\ ${ }^{2}$ Institute of Geography, University of Osnabrück, Osnabrück, Germany \\ Email: fkholtmeier@arcor.de, Gabriele.Broll@uni-osnabrueck.de
}

How to cite this paper: Holtmeier, F.-K. and Broll, G. (2018) Subalpine Forest and Treeline Ecotone under the Influence of Disturbances: A Review. Journal of Environmental Protection, 9, 815-845. https://doi.org/10.4236/jep.2018.97051

Received: April 20, 2018

Accepted: June 26, 2018

Published: June 29, 2018

Copyright $\odot 2018$ by authors and Scientific Research Publishing Inc. This work is licensed under the Creative Commons Attribution International License (CC BY 4.0).

http://creativecommons.org/licenses/by/4.0/

(c) (i) Open Access

\begin{abstract}
This article considers disturbances caused by abiotic and biotic factors and human impact in the ecological region extending from subalpine forest to the upper tree limit. Both abiotic and biotic factors may cause reversible or irreversible disturbances. Disturbances by mass movement and avalanches give the subalpine forest and the treeline ecotone a distinct spatial pattern characterized by forest on safe topography and sites that preclude forest. Removal of the upper subalpine forests by humans has enlarged the snow-catchment area of avalanches and elongated the avalanche pathways. Consequently, avalanche destructive potential has increased. Hazards will probably increase due to climate change. External factors, like cyclonic storms, may cause fundamental disturbances. Fires have played a major role in the removal of high-elevation forests. Forest destruction by fire is often followed by soil erosion. Wild fires are likely to increase as a result of warming climate and would possibly prevent climatically-driven treeline advance. Cyclic or episodic mass outbreaks of defoliating insects and bark beetles, and pathogens also cause severe disturbances. Oversized populations of wild ungulates impede tree regeneration and can cause local soil erosion. Inadequate game management is the primary cause of intolerable ungulate numbers. Due to man-caused habitat fragmentation, the animals' impact on the remained habitats has increased. Subalpine forest may recover from disturbance or become replaced by a substitute formation (e.g. krummholz). A subsequent absence of natural disturbances may also be considered a disturbance initiating a new development. Both natural and anthropogenic disturbances may counteract positive influences of climatic warming on subalpine forests and treeline. Effective measures to reduce or prevent abiotic and biotic disturbances of high-elevation forest may contri-
\end{abstract}


bute to greater safety for people living in the endangered areas of the mountain valleys and also improve other ecosystem services of the subalpine forest.

\section{Keywords}

Abiotic Disturbances, Biotic Disturbances, Human Impact

\section{Introduction}

Treeline is the transition zone (ecotone) reaching from closed subalpine or northern forests to the outliers of tree growth in the mountain or arctic tundra. The transition zone is characterized by a mosaic of usually scattered and climatically stunted groups and solitary trees interspersed with patches of subalpine or subarctic/arctic vegetation. The width of the ecotone may vary considerably in dependence from the local conditions.

Subalpine forests and the treeline ecotone are strongly influenced by abiotic (e.g., climate, landslides, avalanches, soil erosion, wild fires) and biotic factors (defoliating insects, herbivores, bark beetles). Theoretically, on an ideal smooth, uniform slope with uniform climate, and soil, the treeline would run parallel to the contour lines. The treeline could then coincide with the position of an isotherm (mean air or soil temperatures) above which trees could not exist. In nature, however, and at a local scale treeline position is usually not identical with the position of an apparent critical isotherm. The differences are due to the influence of local topography on site conditions, and disturbances which might be equally important.

We desist from entering the general discussion about the term "disturbance" [1] [2] [3]. In the context of the present paper we consider changes caused by natural abiotic and biotic factors as disturbances. These are "normal" events in the high mountain environment and may occur at almost regular intervals or episodically. Disturbances can be caused by both local agents (e.g., avalanches, rockfalls, and debris slides) and large-scale events such as severe cyclonic storms, extremely snow-rich winters, and lengthy droughts (Figure 1). Both abiotic and biotic factors may cause fundamental reversible or irreversible disturbances in subalpine forests and in the treeline ecotone. The time span may also play an important role in this respect. Thus, total removal of a forest by a larger landslide, for example, is unlikely to be compensated by regrowth in the forseeable future. On the other hand, wind throw or burn area will be recolonized by forest, if no adverse factors prevail within less than a hundred years.

Gravitational mass movements such as landslides, debris avalanches, and rockfalls are abrupt and rapid, and they are usually very destructive as are also snow avalanches. Solifluction and soil creep, on the other hand, are mostly relatively slow processes. These are usually restricted to comparatively small areas 


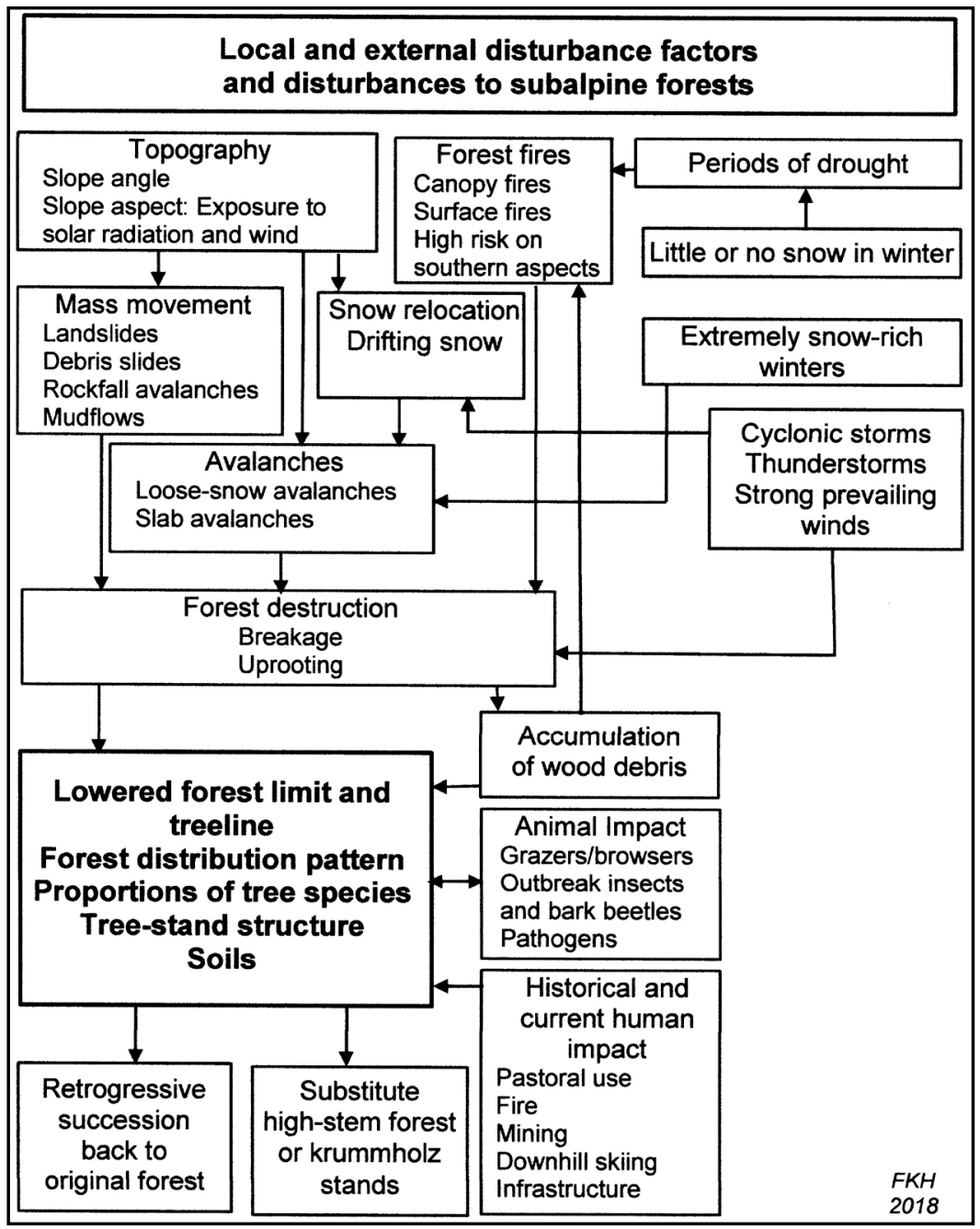

Figure 1. The influence of disturbance factors and disturbances on subalpine forest and the treeline ecotone.

in the treeline ecotone. They play a minor role in the subalpine forest. Biotic disturbances such as defoliation during mass outbreaks of leaf-eating insects and bark beetles, for example, usually cover several years. Not least, the successional development of the forests stand plays a decisive role [4].

In addition to natural disturbances, historical anthropogenic impact has been influencing species composition, age structures, and dynamics of the current high-elevation forests and the treeline ecotone on landscape and local scales [5] [6].

Although abundant literature exists on disturbances in high mountain areas (e.g., review in [7]), relatively little attention has been paid to their specific role in subalpine forests and treeline causation, elevational position, physiognomy (spatial patterns, growth forms, etc.) and dynamics. There however are a few exceptions (e.g., [5] [7]-[21]. Nevertheless, disturbances may overrule positive influences of the warming climate on subalpine forests and treeline (e.g., [5] [12] [16] [22] [23] [24] [25]). 
In this review article, the effects of both natural and human disturbances on subalpine forest and treeline spatial pattern, physiognomy, ecological conditions, and dynamics are considered by means of examples from outwith the tropics (the extratropical zones, Midlatitudes to the Subarctic).

\section{Abiotic Disturbances}

Landslides, debris avalanches, snow avalanches, and mudflows are the most spectacular disturbances on steep mountains. Mass movement may destroy subalpine forests completely and impede or prevent recovery. Otherwise, disturbances (e.g., wild fires) can facilitate expansion of certain tree species while being harmful to others (see below).

\subsection{Mass Movement}

Mass movement from above the treeline occurs on steep mountain terrain in all climatic zones. Weathering debris translocated from usually steep, rocky upper slopes accumulates on the lower, more gentle slopes (e.g., trough shoulders, old up-lifted valley terraces) as talus cones, for example. Merged talus cones often mantle the entire footzone of rockfall cliffs. Recurrent supply with slope debris from the upper slopes interrupts soil formation and may prevent the forest from reaching its potential climatic limit. Single trees and tree groups, however, may occasionally become established on structural benches and ledges far above this zone of disturbance where the trees are relatively safe from gravitational disturbances (Figure 2).

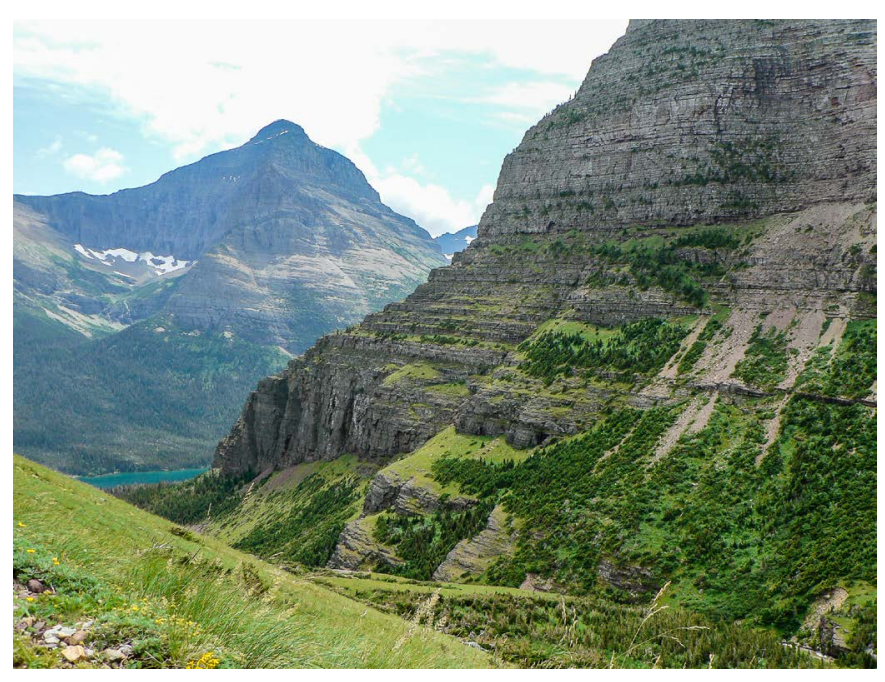

Figure 2. Steep valley side (Trail to Baring Basin, Logan Pass, Montana) of which the lower part is characterized by slightly dipping strata of sedimentary rocks with steep risers (structural benches) alternating with more gentle treads. Subalpine fir (Abies lasiocarpa) and alder scrub (Alnus sinuata) occupy most of the treads, whereas slope debris has largely prevented a closed plant cover on the comparatively small area at the right handside. Nevertheless, fir and alder have been invading the debris slides' runout area. The uppermost occurrences of fir are found on narrow ledges on the steep upper slope. Photo by F.-K. Holtmeier. 
Mass movements may take place at different velocities. Large debris avalanches are usually fast and highly destructive. They eliminate trees often down to the distal end of the runout. Runouts may reach far down into the subalpine forest. Many landslides occur after glacier retreat. The valley sides warm up and become destabilized. Landslides will probably become more frequent in the future due to thawing permafrost (Figure 3) at high elevations [26] [27] [28]. In the long-term ( $>100$ years), consolidated landslide debris will probably be colonized by forest. By contrast, slow processes such as talus creep and solifluction do not necessarily prevent tree establishment [22].

On unstable slope debris, soil formation usually remains at an initial stage for a long time. In such sites, limited availability of moisture and nutrients may be critical for tree establishment, particularly on sun-facing slopes. In the long-term, fine mineral and organic material from pioneer vegetation accumulating between the blocks, can improve site conditions. In the absence of new disturbances, willows, larch, spruce and pine trees or "true" krummholz [29] such as green alder (Alnus viridis) and prostrate mountain pine (Pinus mugo) may gradually colonize debris mantles and talus cones.

\subsection{Snow Avalanches}

Snow avalanches often cause severe disturbances to subalpine forests (outside the tropics). Avalanche formation depends on multipe factors. Any avalanche combining high density with high velocity $\left(\mathrm{v}^{2}\right)$ has a great destructive potential [30] [31] [32]. Solid material (blocks, broken and uprooted trees) carried downslope with the snow masses increases the destructiveness of avalanches.

There are two main groups of avalanches; loose-snow avalanches and slab avalanches. The latter consist of more compacted snow. Slab avalanches are

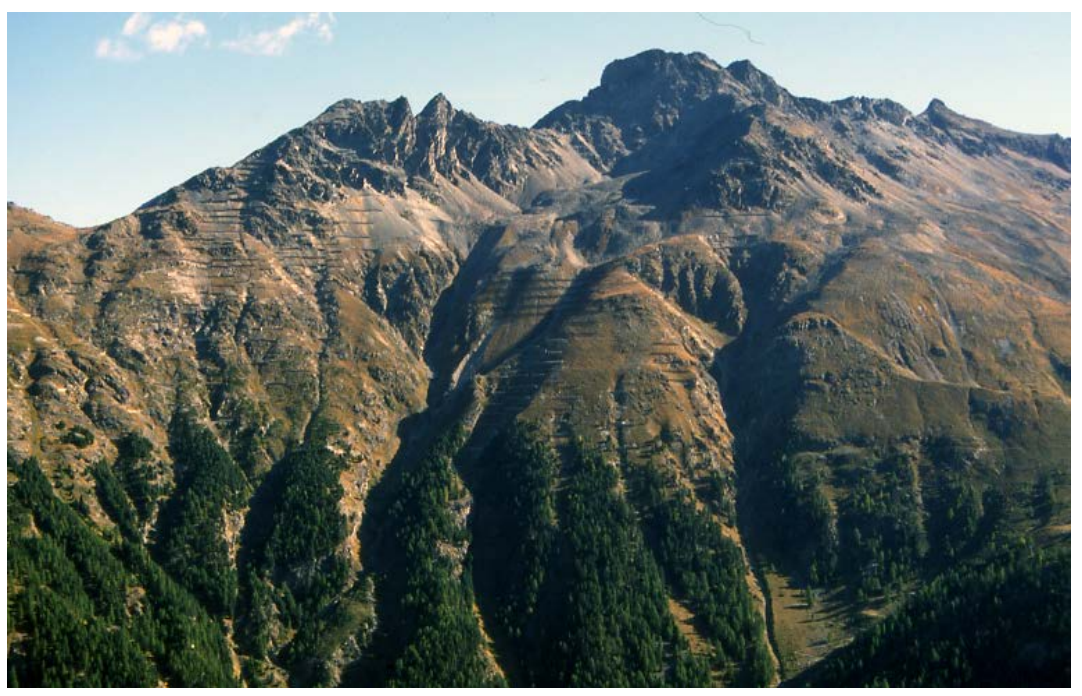

Figure 3. View on the south-west exposed mountain slope (Dos Suors) above Pontresina village (Upper Engadine, Switzerland). Thawing permafrost under coarse block debris in the glacial cirque $(2800 \mathrm{~m})$ may trigger a disastrous debris and mud outburst that would probably follow the gullies and destroy everything on its way. Photo by F.-K. Holtmeier. 
usually confined to discrete areas on mountain slopes. Occasionally, however, the entire mountainside may become affected (Figure 4).

While loose-snow avalanches are usually small and relatively harmless, slab avalanches, consisting of more compacted snow, are highly destructive. Slab avalanches consisting of water, largely saturated snow, ice and entrained soil or rock material (=slush avalanches) may reach extremely high densities (>1000 $\mathrm{kg} / \mathrm{m}^{3}$ ) and therefore have a high destructive potenial. Nevertheless, rapidly moving powder-snow avalanches preceded with a dense cloud of ice crystals may also cause severe damage. The blasts can reach maximum speeds of $>300$ $\mathrm{km} / \mathrm{h}$ [32] [33] [34] [35] [36]. Such an impact the forest cannot usually withstand, especially as the trees are impacted several meters above the ground.

In general, dry flowing avalanches are the most destructive (highest product of speed squared and flow density). In addition, snow glides can occur, especially on smooth grassy slopes. The speed of gliding snow glide is usually low (1 - 100 $\mathrm{mm} / \mathrm{d}$ ). Trees, however, may become uprooted or broken and the ground eroded.

When mountain people have removed the upper subalpine forests to expand the alpine grazing areas, the snow-catchment area of avalanches becomes enlarged and the avalanche pathways elongated. Hence, the destructiveness of avalanches considerably increased. While dense forests with a closed canopy may prevent avalanche formation, open, snow-collecting forests (e.g., former forest pastures) are prone to avalanche formation within the tree stands themselves [37]. In any case, no forest can withstand avalanches that start at high elevation. Most (about 60\%) of the highly destructive avalanches are released far above the anthropogenic forest limit [38] [39]. They often affect comparatively large areas as for example the disastrous avalanche event, that occurred near Vinadi (Lower Engadine, Grison) on 18 February 1962. Three slab avalanches started next to each other far above the forest at an altitude of about $2800 \mathrm{~m}$. On an area

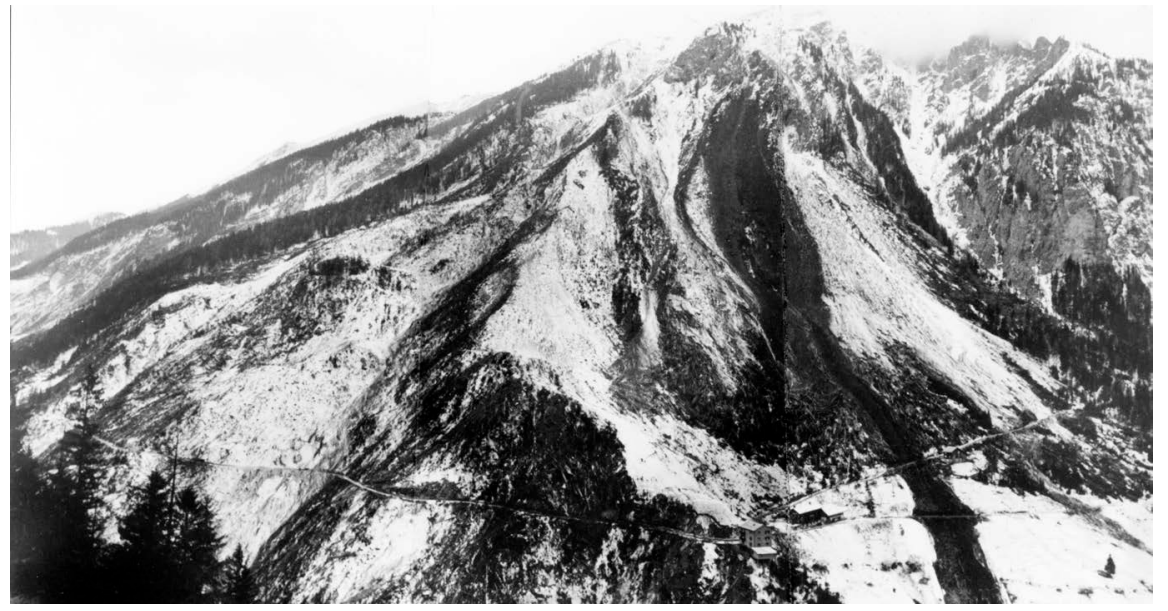

Figure 4. Three slab avalanches that started next to each other destroyed about 100 hectares of protection forests (spruce, mountain pine, larch) above Vinadi (Lower Engadine). Photo by H. Turner, Zürich. 
measuring about $1500 \mathrm{~m}$ in width and $3600 \mathrm{~m}$ in length $\left(>5 \mathrm{~km}^{2}\right)$ about 100 ha of a 120 years-old conifer forest was completely destroyed [40] [41]. The mixture of snow and broken or uprooted trees had increased the destructive force of the avalanche (cf. Figure 4).

Intervals between avalanches can vary between several times a year to once in a few hundred years [32]. Mountain slopes with an inclination of $30^{\circ}-45^{\circ}$ are particularly prone to avalanches. On steeper slopes $\left(>50^{\circ}\right)$, no big snow masses normally accumulate that could produce avalanches. From low-angle terrain $\left(<28^{\circ}\right)$ avalanches are usually absent [30] [35]. Drifting snow, forming leeward cornices and accumulation of snow in gullies, increases the risk of avalanches. Snow-rich gullies are particularly prone to avalanche release. Collapsing cornices often trigger avalanches. Gullies channelize avalanches. In converging gullies, avalanche snow mass and destructive energy may increase. Avalanches often destroy the forest down to the lower slope foot zone. Thus, they create a spatial pattern of avalanche pathways alternating with strips of undamaged high-stem forest (Figure 5). As the forest belt narrows towards high-lying valley heads, intense fragmentation of the forest and decline of the treeline towards the valley heads, are all typical of this area ("Valley phenomenon").

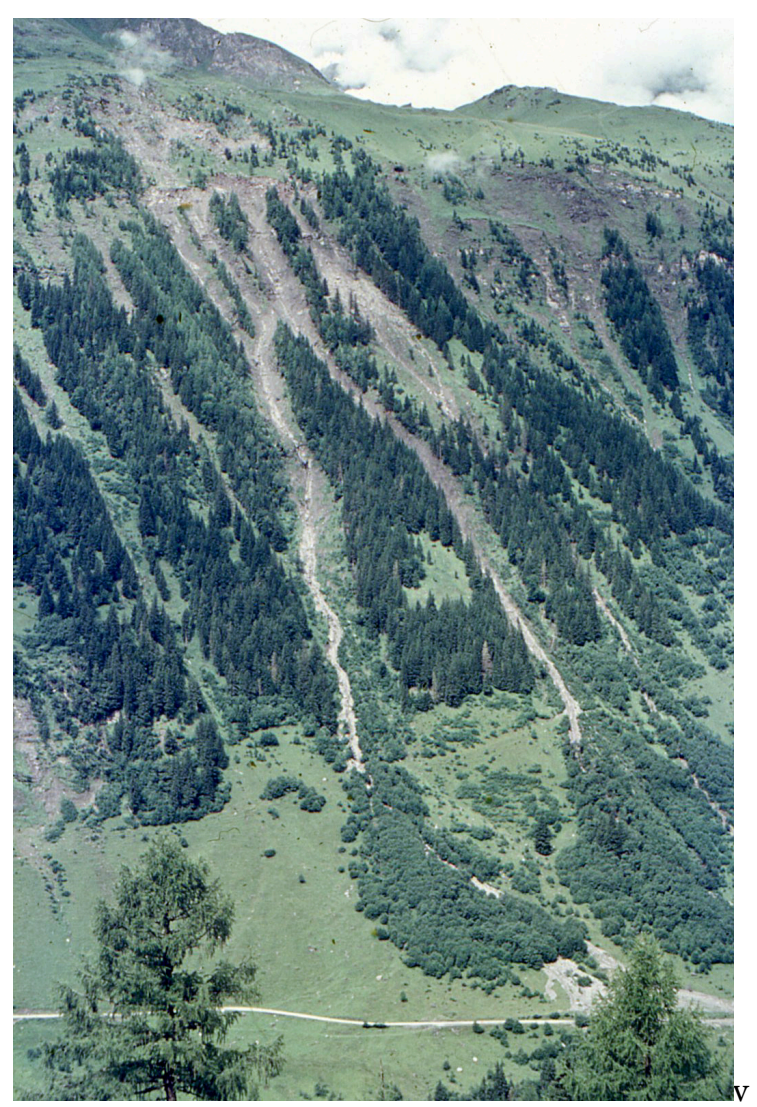

Figure 5. East-facing slope of the Ferleiten Valley (Grossglockner, Austria). The subalpine forest belt is split up by avalanche pathways. High-stem forest is restricted to safe terrain separating the avalanche pathways. Green alder (Alnus viridis) locally occupies the avalanche pathways and forms dense stands in the runouts. Photo by F.-K. Holtmeier. 
Both debris slides and avalanches, not only destroy most trees in their pathways, but also cause distinct changes in the physiognomy of surviving trees. The distribution pattern of intolerant tree and scrub species also changes. The latter are less susceptible to mechanical damage by avalanches and debris slides. Norway spruce (Picea abies), European larch (Larix decidua), and Swiss stone pine (Pinus cembra) occasionally become established in avalanche and debris flow pathways. The trees can only exist in these sites as long as their stems are flexible enough to bend down under the pressure of the snow masses without breaking off [22] [42]. Stems that lose their elasticity can no longer resist avalanches. Larch and spruce are more flexible than Swiss stone pine. In response to disturbance through snow creep, snow slides and avalanches, trees that survive display a multitude of growth forms reflecting mechanical impacts (e.g., [5] [43] [44]).

At short avalanche intervals (a few years) elimination of occasional young trees is very likely. Avalanches may also remove ground vegetation and soil. Young evergreen conifers that survived avalanches often fall victim to parasitic snow fungi (Herpotrichia juniperi, Herpotrichia coulteri, Gremeniella abietina, Phacidium infestans) [43] [45] [46].

Natural succession usually starts mainly with grasses, tall herbs, and willows. Young growth of subalpine conifers and deciduous trees is also found. During long intervals (e.g., $\geq 60 \mathrm{yrs}$ ) between avalanche events, even trees intolerant of stem breakage and almost unable to recover from avalanche disturbances (Pinus cembra) may become established in the avalanche pathways. These trees can grow to several meters in height before the next destructive avalanche breaks them or turns them over. The pathways of large recurrent destructive avalanches hardly ever recover with mature forest in the long-term (>100 yrs [47] [48]).

"True Krummholz" [29] is characterized by inherent decumbent growth, like prostrate mountain pine (Pinus mugo), green alder (Alnus viridis), and willows (Salix $s p$.). This characteristic provides a clear advantage. In cases of low disturbance frequency, these krummholz species may allow the colonization of avalanche-prone terrain, talus cones and slope debris mantles. The krummholz species can recover from breakage through sprouting from the root stock and/or release of vertical stems from layered branches [29] [43] [44] [49] [50] [51] [52]. Birch (Betula pubescens) is also found in such locations. These are probably the only sites within the subalpine forest zone where birch may persist in the long-term [5] [22] [53]. In the Rocky Mountains, dense clonal stands of trembling aspen (Populus tremuloides) often occupy avalanche pathways (Figure 6). "Krummholz" may be considered a substitute formation of the high-stemmed subalpine forests in such places. Similar substitute formations also exist in other high mountains, as for example in the Carpathian Mountains [54] and in the Himalayas (e.g., [5] [55] [56] [57] [58] [59]).

While the substitution of normal, erect tree species and facilitation of woody scrub are typical of slopes prone to recurrent avalanches and debris slides, it depends however on slope aspect and substrate as to whether prostrate mountain 


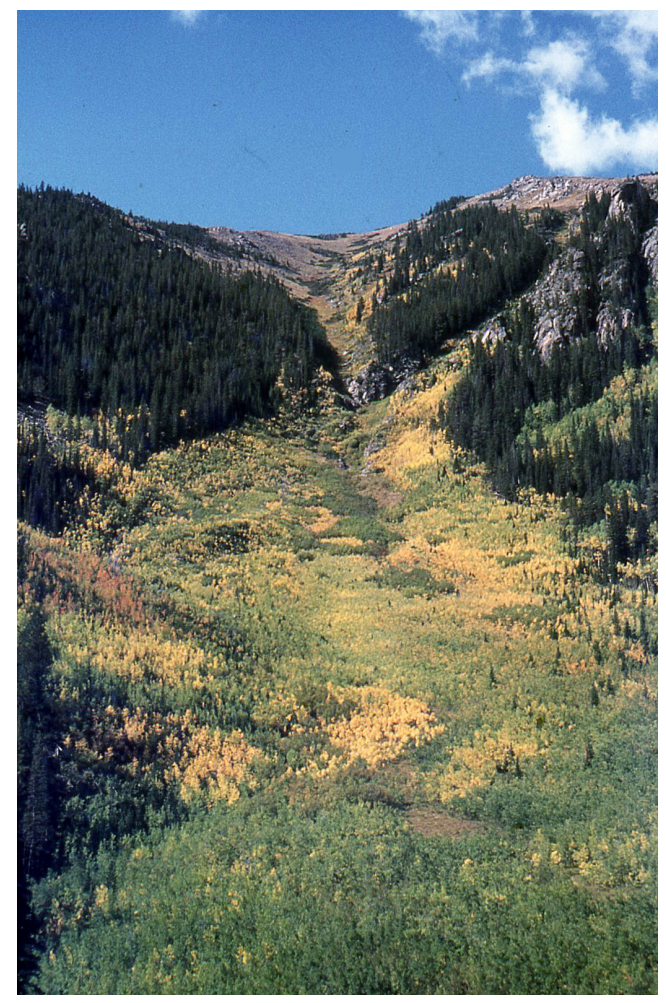

Figure 6. Dense aspen (Populus tremuloides) stands have colonized this avalanche pathway on a mountain side at Berthoud Pass, Colorado Front Range. The aspen stands consist of different clonal groups as is reflected in the autumn colours. Photo by F.-K. Holtmeier.

pine or green alder are found in such places. Drought-tolerant prostrate mountain pine typically occurs on sun-exposed slopes and carbonatic substrate. Green alder, on the other hand, occupies corresponding sites on shady and moist slopes, seemingly with a preference for silicate substrate. Obviously, however, it is soil moisture, rather than soil acidity, that makes the difference (e.g., [47] [60]). Soil moisture (meltwater, seepage) is increased by late-lying avalanche snow.

Thus, on both sunny avalanche slopes and areas with shady aspects, thickets of green alder and prostrate mountain pine may be found next to each other. The small-scale distribution of these krummholz species however usually varies due to the local climatic conditions. On sun-facing avalanche-controlled slopes in the relatively continental Upper Engadine (Switzerland), for example, green alder is mostly found in moist (and nutrient-rich) gullies, along rivulets and at the lower rim of screes, where seepage comes near to the surface. In such areas, extensive stands of Pinus mugo may cover the relatively dry terrain. On avalanche-affected moist north-facing slopes, prostrate mountain pine is usually restricted to less snow-rich and drier microtopography, such as small ridges separating gullies (Figure 7), while being outcompeted by green alder in the moist locations [47] [48] [60]. Late lying avalanche snow masses support parasitic snow fungi infection of prostrate mountain pine in such sites. 


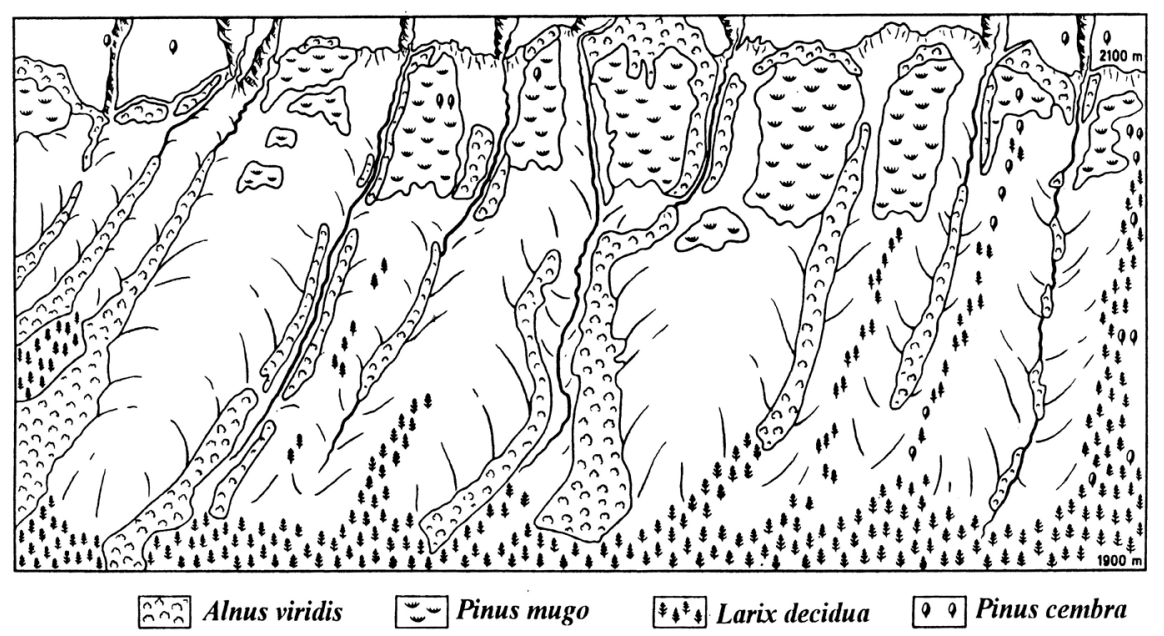

Figure 7. Distribution of Alnus viridis, Pinus mugo, Pinus cembra, and Larix decidua on the northeast-facing slope of the Bernina Valley (Upper Engadine). Alnus viridis grows in the avalanche prone gullies with late-lying snow and just below the steep rockwalls (upper slope). Pinus mugo occupies the relatively dry ridges. Pinus cembra is restricted to sites safe from avalanches, while scattered Larix decidua is found at the outer rim of the avalanche pathways and in the runout.

In the case of increasing winter precipitation due to climate change more snow will probably accumulate above the subalpine forests. Thus, the risk of disastrous avalanches will increase [61] [62] [63], particularly when big snow masses accumulate during a few days of extreme synoptic conditions. In addition, damage to vegetation and soils by gliding snow will increase.

\subsection{Severe Storms}

Severe storms may cause windthrow and also stem and crown breakage on wide areas. In the Alps, for example, winter storms like Vivian (1990) and Lothar (1999) destroyed mountain forests in many high-mountain valleys (e.g., [64]). Storm damage was positively correlated with the height of tree stands and stem diameter. Tree stands on soaked, fine-textured soil were particularly affected.

Windthrow causes abrupt changes of the ecological conditions in the windthrow areas (cf. Figure 1). The amount of litter and litter quality change completely, and the heat and water balance of the topsoil also alter. Myorrhization is affected. Higher temperatures stimulate biological activity. Consequently, decomposition and nutrient availablity increase. Bark beetles profit from the high amount of deadwood. Removal of deadwood can help to minimize bark beetle expansion. On the other hand, broken stems and standing deadwood reduce avalanche release within the windthrow areas. Wild ungulates (red deer, roe deer, and chamois) benefit from increased protein-rich forage supply on the disturbed areas. Natural reforestation of the windthrow areas largely depends on the distance from the seed sources. The smaller the area of windthrow is, the higher the seedling and young growth densities are [65].

Trees in the treeline ecotone are usually less affected by storms. This might be 
due to reduced tree stature and high mechanical resistance of the treeline-forming tree species (see also [66]). Nevertheless, permanent stress by strong winds from a prevailing direction may shape the trees' growth form (e.g., [67] [68] [69] [70] [71]).

\subsection{Wildfires and Man-Ignited Fires}

Both wildfires and man-ignited fires have affected subalpine forests throughout landscape history (e.g., [5] and references therein [72] [73]). Fire types, fire frequency, intensities and after-effects depend on a multitude of locally and regionally varying preconditions: climate, location and orientation of mountain ranges and mountain valleys, slope exposure to prevailing winds, forests' species composition, stem- and crown-density, spatial structures, and successional stages [74]. Thus, generalization is problematic.

On slopes controlled by upslope winds, fires may spread rapidly from the closed forests to higher elevation and affect subalpine forest and the treeline ecotone (Figure 8). As to the effects of fires, the different fire-tolerance of the tree species plays an important role. In the European Alps, for example, larch having a thick insulating cork-like bark and annually renewing needles, is highly fire-tolerant, whereas evergreen Swiss stone pine and spruce are very vulnerable. In the Rocky Mountains, whitebark pine is usually not much affected by light surface fires, whereas Engelmann spruce and subalpine fir are intolerant (e.g., [75] [76]).

Wildfires are often associated with periods of drought. In the Rocky Mountains, the number of forest fires has dramatically increased during the last decades (by about 73\%). Higher spring temperatures, earlier snowmelt and subsequent dry summers have been the main driving factors [77]. Fire risk increases

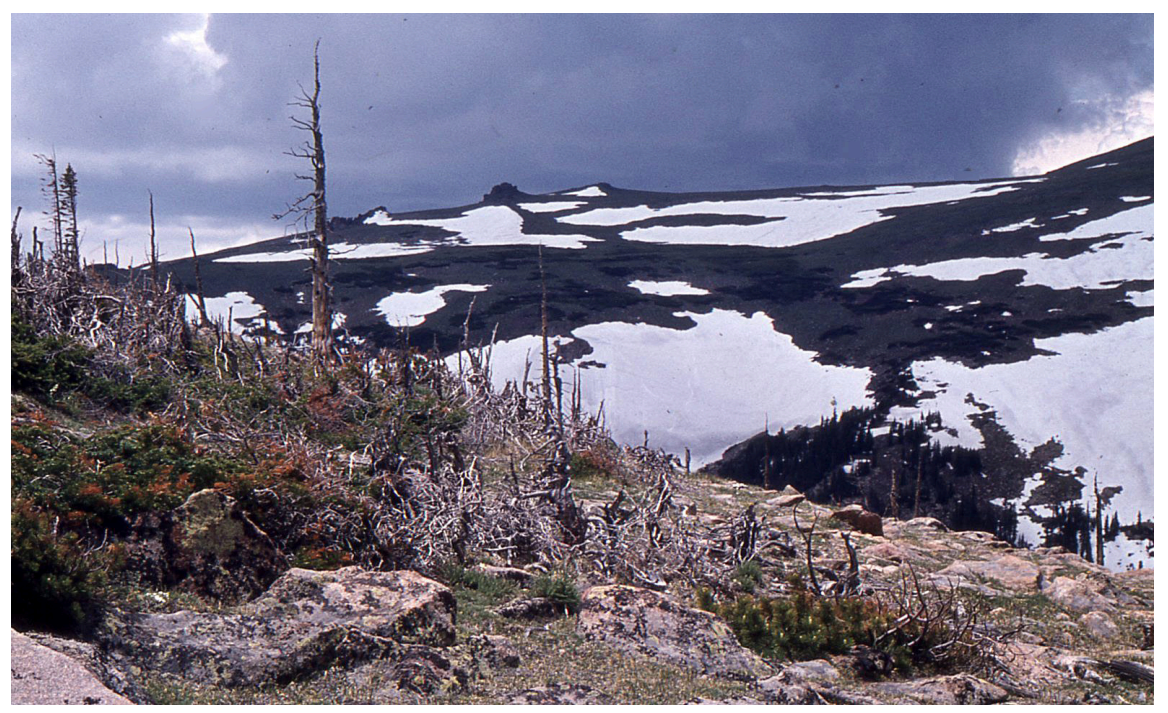

Figure 8. Burn area on Trail Ridge, Rocky Mountain National Park (Colorado) at about $3440 \mathrm{~m}$. View to WNW. The forest fire dates back to the 1870s. Driven by strong wind from the west, the fire spread upslope. Photo by F.-K. Holtmeier. 
in parallel with accumulation of greater amounts of fuel on the forest floor (e.g. [77], for review), as for example, after mass outbreaks of bark beetles. Forests on dry southern aspects are particularly prone to destruction by fire (cf. Figure 1). While fires are most destructive to the closed subalpine forest stands, scattered trees and open tree stands in the treeline ecotone are relatively seldom affected. Even if tree individuals or scattered tree stands are ignited by lightning, for example, the fire will usually not spread over a great distance from the point of ignition (see also [66]). Broad persistent avalanche pathways may act as natural fire breaks.

In harsh treeline environment, recovery from burning by natural succession takes many decades (e.g., [78]) (cf. Figure 8). In the subalpine forests, the absence of wildfires (light surface fires), however, may be considered as a (secondary) disturbance. Shade-tolerant tree species (e.g., spruce, subalpine fire, mountain hemlock = Tsuga mertensiana) that were suppressed by fire, may rapidly outcompete the light demanding tree species. This is of particular importance for example in habitats where whitepark pine is seral [79]. In the long-term, natural regeneration will fail and the forests may become overmature.

Man-caused fires have played a major role in the removal of high-elevation forests (see below). Lightning-ignited fires are comparatively rare (e.g., [80]). In most high mountains of Central Asia overgrazing and particularly burning still are the most important disturbances to the high-elevation forests (e.g., [59]). Forest fires are likely to increase as a result of warming climate (e.g., [73] [74] [81]-[88]). Increased wild fires would possibly prevent climatically-driven treeline advance (e.g., [88]). For the Swiss Alps, the influence of forest fires has been predicted to be even more important than the direct effects of climate change [83].

Total forest destruction by fire is often followed by soil erosion (Figure 9). Erosion intensity, however, varies depending on a multitude of local factors. Slope gradient, intensity and duration of heavy rain and surface runoff, high amounts of melt water, soaked soil (water-saturated soils, avalanches), and substrate susceptibility are involved.

\section{Biotic Disturbances}

The main types of biotic disturbances are 1): mass outbreaks of phyllophagous insects and bark beetles, 2) damage caused to trees, shrubs, ground vegetation and soil by oversized populations of large herbivorous mammals, and 3) pathogens and diseases (e.g., blister rust, parasitic snow fungi).

\subsection{Mass Outbreaks of Leaf-Eating Insects and Bark Beetles}

Mass outbreaks of leaf-eating insects and bark beetles (cf. Figure 1) depend on relatively slow population cycles at intervals of eight to ten years (e.g. [89]-[95]). Outbreak dynamics and intensities are controlled by multiple and partly interacting factors such as thermal deficiency (deep winter frosts), periods of drought, forest composition, and stage of development. For example, if lasting 


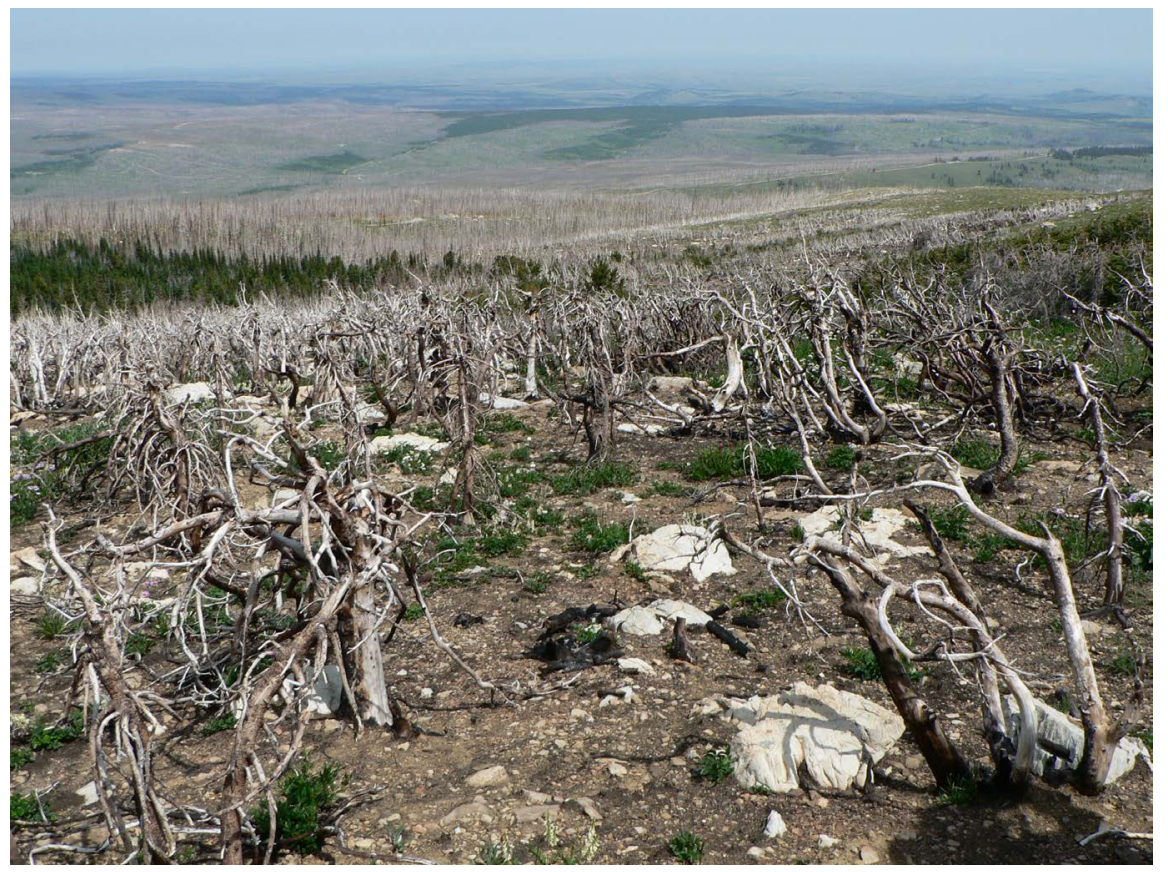

Figure 9. A big forest fire ("Red Eagle Burn”) destroyed subalpine forest and krummholz (Pinus albicaulis) at treeline near Divide Peak (Glacier National Park, Montana) in July 2006. As no organic layer was left, the soil is prone to erosion. Photo by F.-K. Holtmeier.

droughts and poor forest condition coincide, an eruption of bark beetle will be likely [77].

\subsection{Disturbance by Bark Beetle}

Mass outbreaks may be local or affect comparatively large forested areas. Normally, mountain pine beetles kill trees across relatively sparse areas and with minor effects on individual forest stands. On the other hand, outbreaks may be epidemic (e.g., [96] [97] [98] [99]).

Bark beetle infestations (e.g. Dendroctonus ponderosae, Dendroctonus rufipennis) depend on the trees' phloem thickness. Only if the phloem is thick enough, are the beetles able to excavate galleries for oviposition (e.g., [100]). Thus, tree stands with a high proportion of mature trees are prone to bark beetle attacks. Systematic fire suppression has been supposed to support bark beetle mass outbreaks, as trees grow older and bigger in diameter [101]. Bark beetle attacks will not end until the beetles have killed all thick trees or man and/or wildfires have removed them.

Development of forests affected by bark beetle differs depending on whether a single fire or several fires interact with natural succession and beetle population dynamics ([4] [100], and further references therein). Mountain pine beetle and spruce beetle mass outbreaks have lasting effects on the mountain forests composition, structure, and dynamics. Thus, in spruce-fir forests (Picea engelmannii, Abies lasiocarpa) in Colorado $90 \%$ of the trees were spruce and $10 \%$ subalpine fir before a spruce beetle outbreak. Afterwards, the proportion had almost re- 
versed (20\% spruce, $80 \%$ subalpine fir [4] [102] [103]). Mass-outbreaks of bark beetles may also have far-reaching socio-ecological consequences (for review see [104]). A change in fire control would probably have a mitigating effect on mass outbreaks of bark beetle and their effects on subalpine whitebark pine forests.

\subsection{Disturbance by Autumnal Moth and Winter Moth}

In northernmost Finland and adjacent Norwegian areas, hundreds and in places up to thousands of square kilometers of subarctic mountain birch forests were destroyed, or else severely affected during the peak of a major mass outbreak of the autumnal moth (Epirrita autumnata) during the 1960s, for example. In the past, mass outbreaks occured at intervals of 9 - 11 years [89] [105]. During the last decades, however, the clear cyclicity of outbreaks has disappeared in the more continental areas or else become more episodic [92] [105].

Depending on the local conditions, however, defoliation may occasionally be restricted to smaller areas, such as a single mountain slope ([4] [5], many references therein). For example, a mass outbreak of the autumnal moth on Ailigas mountain (620 m, east of Karigasniemi village, Finnish Lapland) in 1927 caused a depression of the upper birch forest limit [106]. Afterwards, birch forest has not moved upslope again (personal observation 2008). There is some evidence [107] [108] that also in northernmost Finnish Lapland the birch treeline had declined due to Epirrita outbreaks. This has been concluded from numerous rotten birch stumps far above the current mountain birch forests [108]. During the last two decades the winter moth (Operophtera brumata) expanded to the northeast of northern Fennoscandia. A warmer climate has possibly been the driving factor. This area was previously occupied by the autumnal moth only [109]. The overlapping disturbances through both geometrids will probably have lasting ecological consequences for the mountain birch, especially when combined with overgrazing by reindeer.

\subsection{Disturbances by Larch Bud Moth}

In the Central Alps, larch bud moth (Zeitraphera diniana) eruptions have caused complete needle loss in pure larch forests at intervals of eight to ten years. Larch bud moth usually attacks subalpine larch stands within the so-called warm slope zone. Larch stands in the treeline ecotone and also just above the valley bottom, are relatively safe from defoliation [4] [5] [110]. The absence of defoliation below and above the warm slope zone is very likely due to delayed needle flush, rather than to extremely low frost temperatures. The over-wintering eggs of the larch bud moth are highly frost tolerant. Even temperatures below $-40^{\circ} \mathrm{C}$ would not kill them. If the caterpillars, however, hatch before needle flush they will die from starvation [110]. Larch bud moth mass-outbreaks are associated with reduction of diameter growth and failure of seed production [4] [22] [111] [112] [113]. Complete dieback of larch may occur after two consective summers with total needle loss. After complete defoliation, the larch bud-moth caterpillars may 
attack young successional Swiss stone pines in the forest understorey. The pines damaged by the larch bud moth are highly susceptible to secondary noxious insects. Thus, they are at greater risk to be killed than the larch trees in the overstorey [114] [115].

Disturbance through the larch bud moth could be reduced by giving free rein to natural succession: This would support Swiss stone pine, Norway spruce, and arboreous mountain pine (Pinus montana). Larch, however, is preferred as it has a higher economic value compared with the other conifer species. Therefore, instead of reducing the proportion of larch, artificial disturbances are used in the present mixed larch-stone pine forests to facilitate the establishment of larch seedlings. These disturbances include removal of the ground vegetation, exposure of the mineral soil, and creation of sunlit microsites. Facilitation of larch would probably be appropriate in the lower subalpine forest, where production of high-quality timber (construction wood) can be expected. In the upper subalpine forests, however, severe high-elevation climate impairs the growth of merchandable timber.

While from a short-term perspective, the mass outbreaks appear as "ecological catastrophes", they can turn out to be a factor stabilizing the existing pure or larch-dominated forests in the long-term. The outbreaks interrupt the natural succession towards the climax stage that would be dominated by Swiss stone pine. Although the recurrent larch bud moth eruptions did not eliminate larch forests, they however reduce their esthetic value. The seasonally changing bright foliage colours of this deciduous conifer make them very attractive for tourists [47] [60].

\subsection{Disturbances by Pathogens}

In addition to outbreaks of leaf-eating insects and bark beetles, pathogens (cf. Figure 1) are strong disturbance factors (for reviews see [4] [5] [116]). The role of snow fungi infections as strong disturbance factors has already been addressed in context with avalanche disturbances. However, these fungi can also cause severe damage to high-altitude afforestation and spontaneous young growth (e.g., [16] [117] [118] [119] [120]).

Disturbance by blister rust (Cronartium ribicola) is another example. Blister rust was accidentally introduced from Europe to North America in 1910 [121]. While European Swiss stone pine is highly resistant to this fungal disease, blister rust has destroyed extensive whitebark pine stands in the Rocky Mountains. It appears that blister rust is threatening the existence whitebark pine of this pine species in the Rockies. Subalpine whitebark pine forests are important habitats of many animal species, among them grizzly bear (Ursus arctos horribilis) that relies on the heavy energy-rich seeds of whitebark pine for hibernation [122] [123]. Thus, the economic losses due to expanding blister rust, however, are by far less important than its ecological impact on the animals' habitat.

Pines affected by blister rust are highly prone to assaults by mountain bark beetle [124] [125]. Not only whitebark pine at lower elevations but also pine 
stands and young growth at the subalpine forest limit are affected. In the long-term, the entire subalpine ecosystem will be seriously disturbed by this invasive pathogen [122] [126] [127] [128] [129]. In the treeline ecotone, solitary whitebark pines providing shelter from wind may facilitate the establishment of Engelmann spruce and subalpine fir at their downwind edge and initate the development of tree islands [130] [131]. Thus, blister rust is acting opposite to a possible climatically-driven forest advance to greater elevations.

\subsection{Disturbances by Oversized Populations of Wild Ungulates}

Animals' impacts must be considered in the mountain landscape context. Composition, age structures and dynamics of subalpine forest and the present treeline landscape have been continuously influenced by human activities (e.g., pastoral and forest use, mining, charcoal production). As kind and extent of man's influences vary regionally and locally, the possibility of generalization is limited. Conclusions by analogy would run the risk of disguising problems and preventing in-depth effects.

Disturbances by oversized ungulate populations usually are more locally restricted than those caused by mass outbreak of insects. Wild ungulates, particularly cervids have locally suppressed tree regeneration and self-maintenance of tree stands at the altitudinal treeline. Treeline tree species become affected at varying intensities [116].

Originally, ungulate-populations were controlled by natural regulation whenever they exceeded the habitat carrying capacity [4]. This has changed due to human impact. In most cases, inadequate game management and habitat fragmentation due to landscape use are the primary causes of "over-sized" deer populations [4] [5] [116], for further references. In the Alps, for example, natural seasonal migration routes of red deer from the mountains to the foreland have become interruped by expanding landscape use, roads, highways, railway, and channels. Seasonal migrations had prevented overuse of the alpine summer grazing areas. The riparian forests in the mountain foreland and also on the bottoms of the mountain valleys, had previously been important winter grazing habitats. In addition, expanding tourism and infrastructure in the Alps have caused considerable habitat losses. Consequently, impact of wild ungulate populations on the remained high elevation habitats has increased. Now, it often exceeds the carrying capacity of the fragmented habitats. Natural young growth in the subalpine forest and in the treeline ecotone usually suffers more from wild ungulates than afforestation at high elevation [119] [132].

In northernmost Finland, excessively high numbers of semi-domesticated reindeer are an important disturbance factor in the treeline ecotone and mountain tundra [22] [116] [133]. In the overgrazed areas, soil erosion has increased (Figure 10). As in the case of over-sized red deer populations, the problem is man-made ([4] [22] [134] [116] for details). In some neighbored areas of northern Finnmark (Norway), the effects of overgrazing on ground vegetation and soil erosion were already visible on satellite images taken more than twenty years 


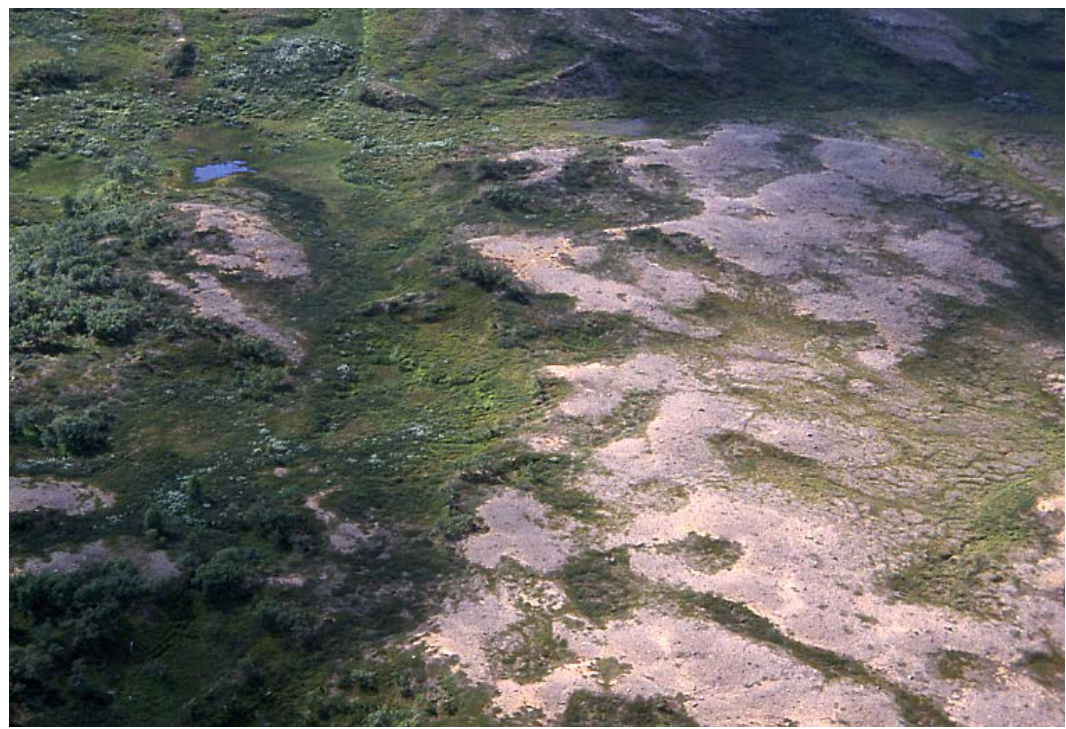

Figure 10. On the north-facing slope of Koahppeloaivi (northernmost Finland), the soil has eroded completely from convex, wind-swept topography after reindeer disintegrated the plant cover, and birch stands declined due to recurrent defoliation by the autumnal moth (Epirrita autumnata). Photo by F.-K. Holtmeier from about $300 \mathrm{~m}$ above ground.

ago [13]. Only reduced reindeer numbers combined with pasture rotation would help to ensure carrying capacity of the summer grazing areas in the long-term [135] [136].

The greatest disturbance to the treeline birch stands, however, is probably the combined effect of overgrazing by reindeer and defoliation during episodic mass outbreaks of the autumnal moth [94] [137] [138] [139] [140]. Mass outbreaks of the autumnal moth and subsequent very cold summers combined with an increased reindeer impact probably enforced birch decline in the past [108]. Effects on seedlings and saplings may locally overrule positive influences of changing climate (e.g., [5] [16] [141]). On the other hand, warming climate has been suggested decreasing phenolic substances in dwarf birch (Betula nana). As a result, higher palatability of the leaves may increase reindeer grazing pressure and adversely affect climatically-driven expansion of this dwarf shrub [142] [143].

\section{Anthropogenic Disturbances}

Anthropogenic disturbances are those that humans have been causing to treeline forests. Pastoralism, cutting trees for fuel, construction, and ore mining (construction wood, charcoal production) have influenced subalpine forests throughout history. In addition, winter mass-tourism, alpine skiing and associated infrastructure have become a severe disturbance affecting both the subalpine forests and the treeline ecotone.

In many high mountains, pastoral use of the subalpine and alpine zones dates back many centuries or even several thousands of years (e.g., [5] [22] [144]-[150]). High-elevation forests were removed to expand the seasonally used alpine graz- 
ing areas into the subalpine zone, wherever accessible to domestic ungulates. Thus, grazing pressure was especially intense on relatively gentle topography, such as trough shoulders and similar terrain (Figure 11). In glacially-moulded valleys, the upper limit of closed subalpine forests became usually located to the upper rim of steep trough walls. Pastoral use impeded natural regeneration of high elevation forests, and many tree stands such became over-mature.

Fire has been used for the past 4500 years to create alpine pastures. In some areas, fire clearing probably started already during the Neolithic [151] [152]. The pastures were burned to remove dwarf shrub vegetation ("weeds") and to maintain or increase pasture productivity. In the Central Alps, highly fire-tolerant larch could expand at the costs of less-tolerant evergreen Swiss stone pine and spruce. In addition, these evergreen conifers were systematically removed to create open, light-flooded larch stands where cattle could graze (subalpine forest pastures). Under natural conditions, pure larch stands would have been restricted to disturbance sites with open mineral soils and sparse ground cover, such as runouts of debris slides and talus cones (Figure 12) [47].

Increasing pure larch forests fuelled mass outbreaks of the larch bud moth. In the Alps, most forest fires were caused by human beings [80]. In the central Alps, clearing alpine pastures by fire considerably decreased during the last 2000 years, probably because forests had been removed long ago from subalpine areas suitable for pastoral use [148]. In many mountain ranges, lasting effects were caused by mining activities combined with consumption of immense quantities of wood (construction, fuel, charcoal production for ore melting). On the heavily grazed subalpine/alpine pastures and on clear-cut areas, soil erosion increased considerably. On the other hand, exposed mineral soil facilitated establishment of wind-mediated tree species (e.g., larch, spruce, mountain pine, birch, aspen, willows).

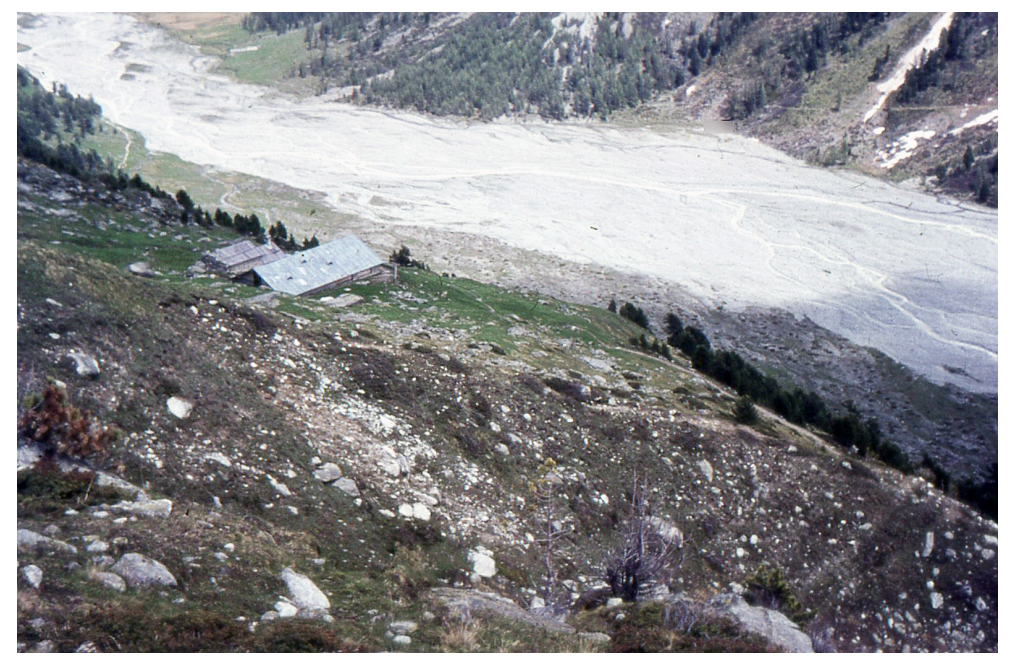

Figure 11. On this SE-facing slope, subalpine Swiss stone pine forest was removed from relatively gentle terrain area for pastoral use. Downslope view from Alp Surovel (Val Roseg, Upper Engadine, Switzerland). Photo by F.-K. Holtmeier. 


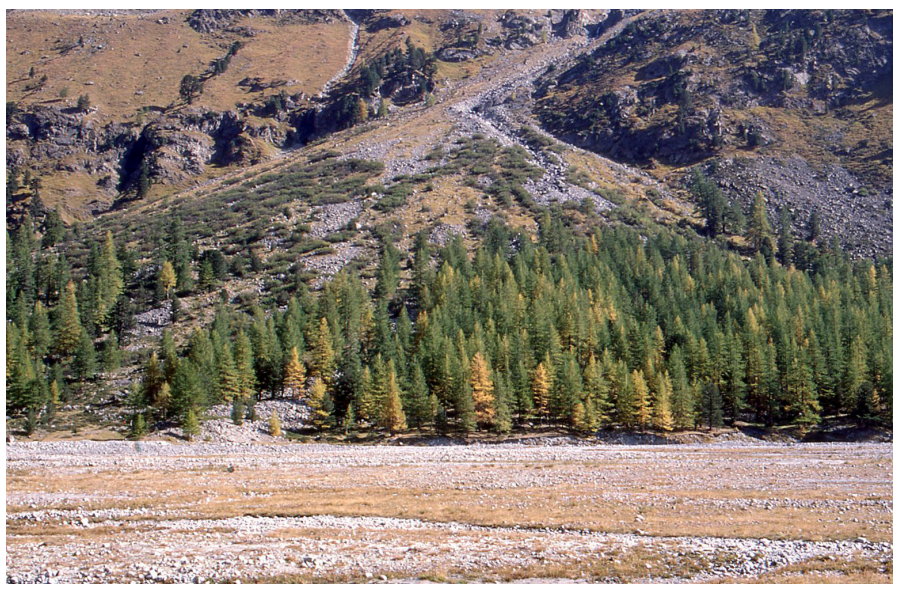

Figure 12. Larch has colonized the avalanche runout. A few Swiss stone pines are admixed. Small pure Swiss stone pine stands are found on rocky cliffs above the talus cone. Alp Misaun, Roseg Valley (Upper Engadine). Photo by F.-K. Holtmeier.

In the high mountains across Europe, the situation has however changed, mainly due to the widespread decline of pastoral use and mining [5] [25] [153] [154]. In the absence of grazing-pressure, grasses can grow to full length. Long downslope-leaning grasses not only reduce surface roughness but also keep snowpack temperatures near the ground around the freezing point. Thus, the risk of snow gliding and avalanches has been increasing. Therefore, with some reservation the decline of centuries-long pastoral use may also be considered a disturbance. In the European Alps, forest cover has increased by about $4 \%$ since the 19th century. Landuse change and afforestation have been the main driving factors. In the medium-term (decades), growing biomass and accumulation of deadwood will increase the susceptibility to disturbances by bark beetle eruptions, windthrow and fire [155]. In most high mountains of Central Asia overgrazing and particularly seasonal burning were and still are the most important disturbances to the high-elevation forests (e.g., [59]).

In the reindeer herding areas, only reduced reindeer numbers combined with pasture rotation would help to ensure the carrying capacity of summer grazing areas in the long-term [135] [136].

In many high-mountains, alpine skiing associated with the creation and maintenance of unobstructed ski runs from the Alpine down to the valley floor has become a severe disturbance affecting both the trees in the treeline ecotone and subalpine forests. On the ski slopes, destruction of the ground vegetation and soil erosion due to the skiers, and the use of heavy equipment are common, though locally more restricted than disturbances by mass movement, avalanches and historical pastoral usage.

\section{Concluding Remarks}

Disturbances caused in subalpine forests through abiotic factors have been omnipresent on steep mountain slopes throughout the Holocene. Mass movement and avalanches have prevented long-term forest establishment on many steep 
mountain slopes. Disturbances disregarded whether natural or anthropogenic, cause, direct and indirect damage (removal, spatial distribution, age structure, sucessional stage, susceptibility, etc.) to subalpine forests. Disturbances are usually locally restricted. They may be abrupt (e.g., by avalanches) or gradual, episodic or periodic (cyclic) (e.g., insect mass-outbreaks).

All abiotic disturbances, disregarded of whether caused by avalanches, debris slides or windthrow, are associated with alterations of the ecological conditions. In the cases where there has been a destruction of subalpine forest stands, there is in place an environment with high light intensity, reduced water-holding capacity of the soil and subsequent increase of surface runoff and soil erosion. Such conditions are highly stressful for the ground vegetation and tree seedlings. Heavily affected subalpine forests and tree stands in the treeline ecotone may or may not recover from disturbance. Depending on whether adverse factors will prevent this, such as recurrent disturbances by avalanches, it may follow that substitute formations such as krummholz may take the place of the original high-stemmed subalpine forests in such places.

In many high mountains, pastoral use, fire and mining have been the most important disturbance factors throughout history. The cessation of traditional pastoral use and surface fires in subalpine forests may be considered a "secondary disturbance". The same applies to the absence of light surface fires (fire suppression), that have been of major importance in natural succession of whitebark pine forest in the Rocky Mountains, and, for example, for larch-Swiss stone pine forests in the Central Alps.

Although disturbances through mass-outbreaks of insects and bark beetles and pathogens are natural in subalpine forests, they have increased due to the anthropogenic impact. Forest management can mitigate the effects.

Changes due to irruptions of the autumnal moth and the winter moth in the mountain birch forests of the European Subarctic combined with heavy grazing pressure by too many reindeer will have lasting ecological and economic consequences. In the long-term, only reduced reindeer numbers combined with pasture rotation would ensure carrying capacity of the grazing areas.

Natural disturbances are likely to increase due to climate change. Mountain areas such as the Alps, the Scandinavian mountain range, and the Rocky Mountains will probably become seriously affected.

Maintenance of subalpine forests and afforestation up to the potential tree limit have been and still are mandatory to create new protective subalpine forests preventing avalanche formation. Successful natural regeneration above the anthropogenic forest limit is of primary importance in this context. Pastoral use should be terminated or reduced at least to the lowest possible intensity. Wild ungulate populations must be strongly controlled and adjusted to the tolerable carrying capacity of the habitats. In combination, these measures may contribute to greater safety for people living in the endangered areas of the mountain valleys and also improve other ecosystem services of the subalpine forest (Figure 13). 


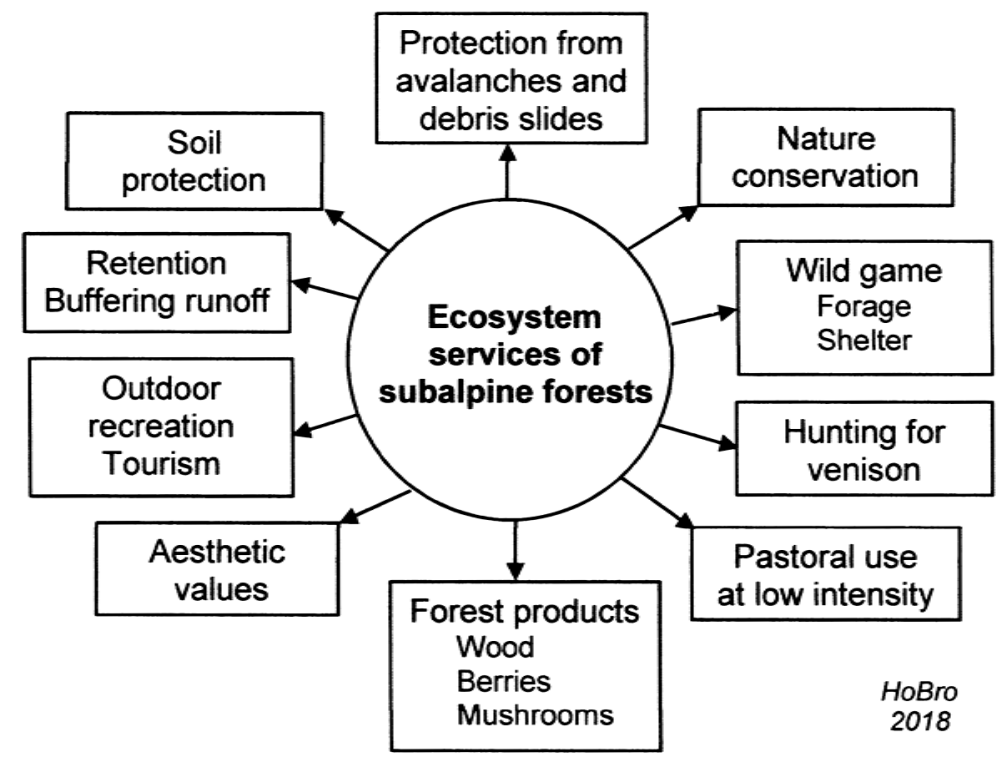

Figure 13. Some ecosystem services of subalpine forests.

\section{Acknowledgements}

We are grateful to Prof. R.M.M. Crawford (St. Andrews, Scotland) for revising the English text.

\section{References}

[1] White, P.S. and Pickett, S.T. (1985) The Ecology of Natural Disturbance and Patch Dynamics. Academic Press, New York.

[2] White, P.S. and Jentsch, A. (2001) The Search for Generality in Studies of Disturbance and Ecosystem Dynamics. Progress in Botany, 62, 399-450.

https://doi.org/10.1007/978-3-642-56849-7_17

[3] Battisti, C., Poeta, G. and Fanelli, G. (2016) The Concept of Disturbance. In: Battisti, C., Poeta, G. and Fanelli, G., Eds., An Introduction to Disturbance Ecology, Springer, Cham, 7-12. https://doi.org/10.1007/978-3-319-32476-0_2

[4] Holtmeier, F.-K. (2015) Animals' Influence on the Landscape and Ecological Importance-Natives, Newcomers, Homecomers. Springer, Dordrecht.

[5] Holtmeier, F.-K. (2009) Mountain Timberlines-Ecology, Patchiness, and Dynamics. Springer, Dordrecht. https://doi.org/10.1007/978-1-4020-9705-8

[6] Holtmeier, F.-K. and Broll, G. (2017) Treelines-Approaches at Different Scales. Sustainability, 9, 808. https://doi.org/10.3390/su9050808

[7] Rogers, P. (1996) Disturbance Ecology and Forest Management: A Review of the Literature. General Technical Report INT-GTR 336, USDA Forest Service, Ogden. https://www.fs.fed.us/rm/pubs_int/int_gtr336.pdf

[8] Butler, D.R. and Walsh, S.J. (1990) Lithologic, Structural, and Topographic Influences on Snow-Avalanche Path Location, Eastern Glacier National Park, Montana. Annals of the Association of American Geographers, 80, 362-378. https://doi.org/10.1111/j.1467-8306.1990.tb00302.x

[9] Butler, D.R. and Walsh, S.J. (1994) Site Characteristics of Debris Flow and their Relationship to Alpine Treeline. Physical Geography, 15, 181-199. 
[10] Butler, D.R. (2001) Geomorphic Process-Disturbance Corridors: A Variation on a Principle of Landscape Ecology. Progress in Physical Geography, 25, 237-248.

[11] Holtmeier, F.-K. and Broll, G. (2007) Treeline Advance-Driving Processes and Adverse Factors. Landscape Online, 1, 1-33. https://doi.org/10.3097/LO.200701

[12] Butler, D.R., Malanson, G.P., Resler, L.M., Walsh, S.J., Wilkerson, F.D., Schmid, G.L. and Sawyer, C. (2009) Chapter 4 Geomorphic Patterns and Processes at Alpine Treeline. In: Butler, D.R., Malanson, G.P., Walsh, S.J. and Fagre, D.B., Eds., The Changing Alpine Treeline: The Example of Glacier National Park, MT, USA, Elsevier, Amsterdam, 63-84. https://doi.org/10.1016/S0928-2025(08)00204-6

[13] Fagre, D.B. (2009) Chapter 1 Introduction: Understanding the Importance of Alpine Treeline Ecotones in Mountain Ecosystems. In: Butler, D.R., Malanson, G.P., Walsh, S.J. and Fagre, D.B., Eds., The Changing Alpine Treeline: The Example of Glacier National Park, MT, USA, Elsevier, Amsterdam, 1-9. https://doi.org/10.1016/S0928-2025(08)00201-0

[14] Wilkerson, F.D. and Schmid, G.L. (2003) Debris Flows in Glacier National Park, Montana: Geomorphology and Hazards. Geomorphology, 55, 317-328. https://doi.org/10.1016/S0169-555X(03)00147-8

[15] Leonelli, G., Pelfini, M. and Morra di Cella, U. (2009) Detecting Climatic Treelines in Italian Alps: The Influence of Geomorphological Factors and Human Impact. Physical Geography, 30, 338-352.

[16] Holtmeier, F.-K. and Broll, G. (2010) Altitudinal and Polar Treelines in the Northern Hemisphere Causes and Response to Climate Change. Polarforschung, 79, 139-153.

[17] Holtmeier, F.-K. and Broll, G. (2010) Wind as an Ecological Agent at Treelines in North America, the Alps, and the European Subarctic. Physical Geography, 31, 203-233.

[18] Holtmeier, F.-K. and Broll, G. (2012) Landform Influences on Treeline Patchiness and Dynamics in a Changing Climate. Physical Geography, 33, 403-437.

[19] Kaczka, R.J., Czajka, B., Łajczak, A., Swagrzyk, J. and Nicia, P. (2015) The Timberline as Result of the Interaction among Forest, Abiotic Environment and Human Acitivity in Babia Góra Mt., Western Carpathians. Geographia Polonica, 88, 177-191. https://doi.org/10.7163/GPol.0023

[20] Kulakowski, D., Barbeito, I., Casteller, A., Kaczka, R.J. and Bebi, P. (2016) Not Only Climate: Interacting Drivers of Treeline Change in Europe. Geographia Polonica, 89, 7-15. https://doi.org/10.7163/GPol.0042

[21] Masseroli, A., Leonelli, G., Bollati, I., Trombino, L. and Pelfini, M. (2016) The Influence of Geomorphological Processes on the Treeline Position in Upper Valtellina (Central Italan Alps). Geografia Fisica et Dinamica Quaternaria, 39, 171-182.

[22] Holtmeier, F.-K. (1974) Geoökologische Beobachtungen und Studien an der subarktischen und alpinen Waldgrenze in vergleichender Sicht: Nördliches Fennoskandien/Zentralalpen (Erdwissenschaftliche Forschung). Franz Steiner Verlag, Wiesbaden.

[23] Holtmeier, F.-K. (1993) Timberlines as Indicators of Climatic Changes: Problems and Research Needs. Paläoklimaforschung, 9, 211-222.

[24] Holtmeier, F.-K. and Broll, G. (2005) Sensitivity and Response of Northern Hemisphere Altitudinal and Polar Treelines to Environmental Change at Landscape and Local Scales. Global Ecology and Biogeography, 14, 395-410. https://doi.org/10.1111/j.1466-822X.2005.00168.x 
[25] Ameztegui, A., Coll, L., Brotons, L. and Ninot, J.M. (2015) Land-Use Legacies Rather than Climate Change Are Driving the Recent Upward Shift of the Mountain Tree Line in the Pyrenees. Gobal Ecology and Biogeography, 25, 263-273. https://doi.org/10.1111/geb.12407

[26] OcCC (2007) Klimaänderung und die Schweiz 2050: Erwartete Auswirkungen auf Umwelt, Gesellschaft und Wirtschaft. http://www.occc.ch/pdf/291.pdf

[27] Haeberli, W., Wegmann. M. and Vonder Muhll, D. (1997) Slope Stability Problems Related to Glacier Shrinkage and Permafrost Degradation in the Alps. Eclogae Geologicae Helvetiae, 90, 407-414.

[28] Haeberli, W., Noetzli, J., Arenson, L., Delaloye, R., Gärtner-Roer, I., Gruber, S., Isaksen, K., Kneisel, C., Krautblatter, M. and Phillips, M. (2010) Mountain Permafrost: Development and Challenges of a Young Research Field. Journal of Glaciology, 56, 1043-1058. https://doi.org/10.3189/002214311796406121

[29] Holtmeier, F.-K. (1981) What Does the Term "Krummholz" Really Mean? Observations with Special Reference to the Alps and the Colorado Front Range. Mountain Research and Development, 1, 253-260. https://doi.org/10.2307/3673062

[30] De Quervain, M. (1972) Lawinenbildung. In: Lawinenschutz in der Schweiz, Ed., Bündnerischer Forstverein and Genossenschaft der bündnerischen Holzprozenten, SELVA, Chur, 15-32.

[31] Perla, R. and Martinelli, M. (1976) Avalanche Handbook. USDA Handbook 489, USDA, Washington DC.

[32] McClung, D. and Schaerer, P. (2006) The Avalanche Handbook. The Mountaineers Books, Seattle.

[33] De Quervain, M. (1965) On Avalanche Classification: A Further Contribution. Publications of the International Association of Scientific Hydrology, 69, 410-417.

[34] der Gand, H.R. and Zupančič, M. (1965) Snow Gliding and Avalanches. Publications of the International Association of Scientific Hydrology, 69, 230-242.

[35] Fraser, C. (1966) The Avalanche Enigma. John Murray Publishers Ltd., London.

[36] Price, L.W. (1981) Mountains and Man: A Study of Process and Environment. University of California Press, Berkeley.

[37] Salm, B. (1979) Snow Forces in Forest Plants. Proceedings of the IUFRO Seminar Mountain Forests and Avalanches, Davos, 25-28 September 1978, 157-181.

[38] Frey, W. (1977) Wechselseitige Beziehungen zwischen Schnee und Pflanze: Eine Zusammenstellung anhand von Literatur. Mitteilungen des Eidgenössischen Instituts für Schnee-und Lawinenforschung, 34, $223 \mathrm{p}$.

[39] Heumader, J. (1987) Gebirgswald und Waldsterben-Mögliche Auswirkungen auf die Schutzfunktionen und denkbare Gegenmaßnahmen durch den Forstdienst und die Wildbach-und Lawinenverbauung. Wildbach-und Lawinenverbau, 51, 21-53.

[40] De Quervain, M. and der Gand, H.R. (1962) Die Schadenslawine vom 18. Februar von Vinadi (Gemeinde Tschlin, Unterengadin). Verhandlungen der Schweizerischen Naturforschenden Gesellschaft, Scuol.

[41] Breu, K. (172) Lawinenschäden. In: De Coulon, M., Ed., Lawinenschutz in der Schweiz. Beiheft Nr. 9 zum Bündnerwald, 7-14.

[42] Johnson, E.A. (1987) The Relative Importance of Snow Avalanche Disturbance and Thinning on Canopy Plant Populations. Ecology, 68, 43-53. https://doi.org/10.2307/1938803

[43] Schönenberger, W. (1978) Ökologie und natürliche Verjüngung von Fichte und 
Bergföhre in Lawinenzügen der nördlichen Voralpen. Berichte der Eidgenössischen Anstalt für das forstliche Versuchswesen, Zürich, 251-261.

[44] Schönenberger, W. (1981) Die Wuchsformen der Bäume an der alpinen Waldgrenze. Schweizerische Zeitschrift für Forstwesen, 13, 149-162.

[45] Roll-Hansen, F. (1989) Phacidium infestans: A Literature Review. European Journal of Forest Pathology, 19, 237-250. https://doi.org/10.1111/j.1439-0329.1989.tb00258.x

[46] Nierhaus-Wunderwald, D. (1996) Pilzkrankheiten in Hochlagen, Biologie und Befallsmerkmale. Wald und Holz, 10, 18-24.

[47] Holtmeier, F.-K. (1967) Die Verbreitung der Holzarten im Oberengadin unter dem Einfluß des Menschen und des Lokalklimas. Erdkunde, 21, 249-258. https://doi.org/10.3112/erdkunde.1967.04.01

[48] Holtmeier, F.-K. (1995) European Larch in Middle Europe, with Special Reference to the Central Alps. In: USDA Forest Service and Intermountain Research Station, Ecology and Management of Larix Forests. A Look Ahead. Proceedings of an International Symposium, Whitefish, Montana, USA, 1992, General Technical Report GTR-INT-319, USDA Forest Service, Ogden, 41-49.

[49] Richard, L. (1968) Écologie de L'aune Vert (Alnus viridis): Facteurs Climatiques et Édaphic. Document pour la Carte de la Végétation des Alpes, 6, 107-158.

[50] Richard, L. (1969) Une Interprétation Éco-physiologique de la Répartition de L'Aune Vert (Alnus viridis). Document Pour la Carte de la Végétation des Alpes, 7, 7-23.

[51] Hafenscherer, J. and Mayer, H. (1986) Standort, Aufbau, Entwicklungsdynamik und Verjüngung von Latschenbeständen im Karwendel (Tirol). Schweizerische Zeitschrift für Forstwesen, 137, 177-203.

[52] Holtmeier, F.-K. and Broll, G. (2017) Layering in the Rocky Mountain Treeline Ecotone: Clonal Conifer Groups' Distribution, Structure, and Functional Role. Trees, 31, 953-965. https://doi.org/10.1007/s00468-017-1520-z

[53] Hibsch-Jetter, C. (1994) Birken in den Alpen: Taxonomisch-Ökologische Untersuchungen an Betula pubescens Erh. und Betula pendula Roth, Contributiones Biologiae Arborum. 6.

[54] Plesnik, P. (1971) Horna Hranica Lesa vo vysokých av Benlanských Tatrách. Vydavatelstvo Slovenskej Akadémie Vied, Bratislava.

[55] Troll, C. (1939) Das Pflanzenkleid des Nanga Parbat. Wissenschaftliche Veröffentlichungen des Deutschen Museums für Länderkunde. Bibliographisches Institut, Leipzig.

[56] Troll, C. (1964) Die klimatische und vegetationsgeographische Gliederung des Himalaya-Sytems. In: Hellmich, W., Ed, Khumbu Himal-Ergebnisse des Forschungsunternehmens Nepal Himalaya, Springer, Berlin, 353-388.

[57] Miehe, G. (1982) Vegetationsgeographische Untersuchungen im Dhaulagiri und Annpurna-Himalaya. Dissertationes Botanicae, 66, Vaduz.

[58] Schickhoff, U. (1993) Das Kaghan-Tal im Westhimalaya (Pakistan): Studien zur landschaftsökologischen Differenzierung und zum Landschaftswandel mit vegetationskundlichem Ansatz. Bonner Geographische Abhandlungen, 87, Bonn.

[59] Schickhoff, U. (2005) The Upper Timberline in the Himalayas, Hindu Kush and Karakorum: A Review of Geographical and Ecological Aspects. In: Broll, G. and Keplin, B., Eds., Mountain Ecosystems. Studies in Treeline Ecology, Springer, Ber- 
lin, 275-354.

https://doi.org/10.1007/3-540-27365-4_12

[60] Holtmeier, F.-K. (1994) Introduction to the Upper Engadine and Its Forests. Proceedings-International Workshop on Subalpine Stone Pines and Their Environment. The Status of Our Knowledge, St. Moritz, 5-11 September 1992, General Technical Report INT-DTR-309, USDA Forest Service, Ogden, 9-17.

[61] Beniston, M. (2001) The Effect of Global Warming on Mountain Regions: A Summary of the 1995 Report of the Intergovernmental Panel on Climate Change. In: Visconti, G., Beniston, M., Ianovelli, E.D. and Varba, D., Eds., Global Change and Protected Areas, Advances in Global Change Research, Springer, Dordrecht, 155-185. https://doi.org/10.1007/0-306-48051-4_17

[62] Patek, M. (2007) Klimawandel und Naturgefahren. Ländlicher Raum, 2007, 1-20. https://www.bmnt.gv.at/dam/jcr:705978fd-74ca-4bba-938b.../Patek_pdf_END.pdf

[63] IPCC (2014) Climate Change 2014: Synthesis Report of Working Groups I, II and III to the Fifth Assessment Report of the Intergovernmental Panel on Climate Change. Geneva.

[64] Schönenberger, W., Angst, C., Bründl, M., Dobbertin, M., Duelli, P., Egli, P., Frey, W., Gerber, W., Kupferschmitt Albisetti, A.D., Lüscher, P., Senn, J., Wermelinger, B. and Wohlgemut, T. (2003) Vivians Erbe. Waldentwicklung nach Windwurf im Gebirge. Eidgenössische Forschungsanstalt WSL. Merkblatt für die Praxis, 36, 1-11.

[65] Schönenberger, W. and Wasem, U. (1999) Der Beginn der Wiederbewaldung von Sturmwurfflächen im Gebirge. In: Fischer, A. and Mössmer, R., Eds., Forschung in Sturmwurf-Ökosystemen Mitteleuropas: Seminar des Fachgebiets Geobotanik und der Bayerischen Landesanstalt für Wald und Forstwirtschaf, Forstwissenschaftliche Fakultät der Universität München, München, 102-110.

[66] Millar, C.I. and Rundel, P.W. (2016) Subalpine Forests. In: Zavaleta, E. and Mooney, H., Eds., Ecosystems of California, University of California Press, Jackson, 579-611.

[67] Holtmeier, F.-K. (1971) Der Einfluß der orographischen Situation auf die Windverhältnisse im Spiegel der Vegetation dargestellt an Beispielen aus dem Val Maroz (Bergell), aus dem Oberengadin und vom Pru del Vent (Puschlav). Erdkunde, 25, 178-195. https://doi.org/10.3112/erdkunde.1971.03.02

[68] Yoshimura, M. (1971) Die Windverbreitung im Gebiet des Mt. Fuji. Erdkunde, 25, 195-198. https://doi.org/10.3112/erdkunde.1971.03.03

[69] Yoshino, M. (1973) Wind-Shaped Trees in the Subalpine Zone of Japan. Arctic and Alpine Research, 3, A115-A126.

[70] Wade, J.J.E. and Hewson, F.W. (1979) Trees as Local Climatic Indicator. Journal of Applied Meteorology, 18, 1182-1187. https://doi.org/10.1175/1520-0450(1979)018<1182:TAALCW >2.0.CO;2

[71] Holtmeier, F.-K. (1980) Influence of Wind on Tree Physiognomy at the Upper Timberline in the Colorado Front Range. Mountain Environments and Subalpine Tree Growth: Proceedings of IUFRO Workshop, Christchurch, November 1979, Technical Paper 70, New Zealand Forest Service, 247-261.

[72] Cunill, R., Soriana, J.M., Bal, M.C., Pèlachs, A., Rodrígez, J.M. and Pérez-Obiol, T. (2013) Holocene High-Altitude Vegetation Dynamics in the Pyrenees: A Pedoanthroecology Contribution to an Interdisciplinary Approach. Quaternary International, 289, 60-70. https://doi.org/10.1016/j.quaint.2012.04.041

[73] Higuera, P.E., Briles, C.E. and Whitlock, C. (2014) Fire-Regime Complacency and Sensitivity to Centennial-Through Millennial-Scale Climate Change in the Rocky 
Mountain Subalpine Forests, Colorado, USA. Journal of Ecology, 102, 1429-1441. https://doi.org/10.1111/1365-2745.12296

[74] Sibold, J.S., Veblen T.T. and Gonzalez, M.E. (2006) Spatial and Temporal Variation on Fire Regimes in Subalpine Forests across the Colorado Front Range in Rocky Mountain National Park, Colorado, USA. Journal of Biogeography, 33, 631-647. https://doi.org/10.1111/j.1365-2699.2005.01404.x

[75] Uchytil, R.J. (1991) Abies lasiocarpa. In: Fire Effects Information System. USDA Forest Service, Rocky Mountain Research Satation, Fire Sciences Laboratory. https://www.feis-crs.org/feis/

[76] Fryer, J.L. (2002) Pinus albicaulis. In: Fire Effects Information System. USDA Forest Service, Rocky Mountain Research Station. http://www.feis-crs.org/feis/

[77] Funk, J., Saunders, S., Standford, T., Easeley, T. and Markham, A. (2014) Rocky Mountain Forests at Risk-Confronting Climate-Driven Impacts from Insects, Wildfires, Heat, and Drought. Report from the Union of Concerned Scientists and the Rocky Mountain Climate Organization, Union of Concerned Scientists, Cambridge. https://www.ucsusa.org/sites/default/files/attach/2014/09/

[78] Kalas, M.M. and Berg, C. (2013) Regeneration of High Montane Plant Communities in the "Nationalpark Kalkalpen" (Northern Alps) after Fire Events. 5th Symposium for Research in Protected Areas, Mittersill, 10-12 June 2013, 331-339.

[79] Arno, S.F. and Weaver T. (1990) Whitebark Pine Community Types and their Patterns on the Landscape. Proceedings-Symposium on Whitebark Pine Ecosystems. Ecology and Management of a High Mountain Resource, Bozeman, 29-31 March 1989, General Technical Report INT-270, USDA Forest Service, Ogden, 97-104.

[80] Sass, O., Hee, M., Leistner, I., Stöger, F., Wetzel, K.-F. and Friedmann, A. (2012) Disturbance, Geomorphic Processes and Regeneration of Wildfire Slope in North Tyrol. Earth Surface Processes and Landforms, 37, 883-894. https://doi.org/10.1002/esp.3221

[81] Camarero, J.J. and Gutiérrez, M. (2004) Pace and Pattern of Recent Treeline Dynamic: Response of Ecotones to Climatic Variability in the Spanish Pyrenees. Climatic Change, 63, 181-200. https://doi.org/10.1023/B:CLIM.0000018507.71343.46

[82] Schoennagel, T., Veblen, T.T. and Romme, W.H. (2004) The Interaction of Fire, Fuels, and Climate Change across Rocky Mountain Forests. BioScience, 54, 661-676. https://doi.org/10.1641/0006-3568(2004)054[0661:TIOFFA]2.0.CO;2

[83] Schumacher, S. and Bugmann, H. (2006) The Relative Importance of Climatic Effects, Wild Fires and Management for Future Landscape Dynamics in the Swiss Alps. Global Change Biology, 12, 1435-1450. https://doi.org/10.1111/j.1365-2486.2006.01188.x

[84] Westerling, A.L., Hidalgo, H.G., Cayan, D.R. and Swetnam, T.W. (2006) Warming and Earlier Spring increase Western US Forest Wildfire Activity. Science, 313, 940-943. https://doi.org/10.1126/science.1128834

[85] Brandes, R. (2007) Waldgrenzen griechischer Hochgebirge. Unter besonderer Berücksichtigung des Taygetos (Waldgrenzdynamik, dendrochronologische Untersuchungen). Erlanger Geographische Arbeiten, Sonderband 36, 1-361.

[86] Batllori, E. (2008) Regional Assessment of Recent Pinus uncinata Alpine Treeline Dynamics in the Pyrenees. Ph.D. Dissertation, University of Barcelona, Barcelona.

[87] Rocca, M.E., Brown, P.M., MacDonald, L.H. and Carrico, C.M. (2014) Climate Change Impacts on Fire Regimes and Key Ecosystem Services in Rocky Mountain Forests. Forest Ecology and Management, 327, 290-305.

https://doi.org/10.1016/j.foreco.2014.04.005 
[88] Halofsky, J.E., Warzinak, T.W., Peterson, D.L. and Ho, J.J. (2017) Understanding and Managing the Effects of Climate Change on Ecosystem Services in the Rocky Mountains. Mountain Research and Development, 37, 340-352. https://doi.org/10.1659/MRD-JOURNAL-D-16-00087.1

[89] Nikula, A. (1993) Animals as Pests in Finnish Lapland. In: Jalkanen, R., Aaalto, A. and Lanti, M.-L., Eds., Forest Pathological Research in Northern Forest with a Social Reference to Abiotic Stress Factors. Extended SNS Meeting in Forest Pathology in Lapland, Finland, 2-7 August 1992, Finnish Forest Research Institute, 22-29.

[90] Bylund, H. (1995) Long-Term Interactions between the Autumnal Moth and Mountain Birch: The Role of Resources, Competition, Natural Enemies and Weather. Ph.D. Dissertation, Sveriges Lantbruksuniversitet, Uppsala.

[91] Tenow, O., Bylund, H., Nilssen, A. and Karlsson, P. (2005) Long Term Influence of Herbivores on Northern Birch Forests. In: Wielgolaski, F.E., Eds., Plant Ecology, Herbivory, and Human Impact in Nordic Mountain Birch Forests, Springer, Berlin, Heidelberg, 165-181.

[92] Neuvonen, S., Niemelä, P. and Virtanen, T. (2000) Climate Change and Insect Outbreak in a Boreal Forests: The Role of Winter Temperatures. Ecological Bulletin, 49, 63-67.

[93] Klemola, T., Hanhimäki, S., Ruohomäki, K., Senn, J., Tarhuanpää, M., Kaitaniemi, P., Ranta, H. and Haukioja, E. (2003) Performance of the Cycle of Autumnal Moth Epirrita autumnata, in Relation to Birch Mast Seeding. Oecologia, 135, 354-361. https://doi.org/10.1007/s00442-003-1194-7

[94] Neuvonen, S., Bylund, H. and Tømmervik, H. (2005) Forests Defoliation Risk in Birch Forests by Insects under Different Climate and Land Use Scenarios in Northern Europe. In: Wielgolaski, F.E., Ed., Plant Ecology, Herbivory and Human Impact in Nordic Mountain Birch Forests, Springer, Berlin, 125-138. https://doi.org/10.1007/3-540-26595-3_9

[95] Neuvonen, S. and Viiri, H. (2017) Changing Climate and Outbreaks of Forest Pest Insects in a Cold Northern Country, Finland. In: Latola, K. and Savela, H., Eds., The Interconnected Arctic - UArctic Congress 2016, Springer, Cham, 49-59.

[96] Logan, J.A. and Powell, J.A. (2001) Ghost Forests, Global Warming, and the Mountain Pine Beetle (Coleoptera: Scolytiddae). American Entomologist, 47, 160-173. https://doi.org/10.1093/ae/47.3.160

[97] Taylor, S.W., Carroll, A.L., Alfaro, R.I. and Safranyik, L. (2006) Forest, Climate and Mountain Pine Beetle Outbreak Dynamics in Western Canada. In: Safranyik, L. and Wilson, B., Eds., The Mountain Pine Beetle: A Synthesis of Biology, Management and Impacts in Lodgepole Pine, Canadian Forest Service, Victoria, 67-94.

[98] Bentz, B.J., Régnière, J., Fettig, C.J., Hansen, E.M., Hayes, J.L., Hickie, J.A., Kelsey, R.G., Negrón, J.F. and Seybold, S.J. (2010) Climate Change and Bark Beetles of the Western United States and Canada: Direct and indirect Effects. BioScience, 60, 602-613. https://doi.org/10.1525/bio.2010.60.8.6

[99] Mitton, J.B. and Ferrenberg, S.M. (2012) Mountain Pine Beetle Develops an unprecedented Summer Generation on Response to Climate Warming. The American Naturalist, 179, E163-E171. https://doi.org/10.1086/665007

[100] Amman, G.D. (1977) The Role of Mountain Pine Beetle in Lodgepole Pine Ecosystems: Impact on Succession. In: Mattson, W.J., Ed., The Role of Arthropods in Forest Ecosystems, Springer, New York, 3-18.

https://doi.org/10.1007/978-3-642-88448-1_1

[101] Johnson, C.G., Clausnitzer, R.R., Mehringer, P.J. and Oliver, C.D. (1994) Biotic and 
Abiotic Processes of Eastside Ecosystems: The Effects of Management on Plant and Community Ecology and on Stand and Landscape Vegetation Dynamics. General Technical Report PNW-GTR 322, USDA Forest Service, Portland. https://doi.org/10.2737/PNW-GTR-322

[102] Schmid, J.M. and Hinds, T.E. (1974) Development of Spruce-Fir Stands Following Spruce Beetle Outbreaks. Colorado, Research Paper RM 131, USDA Forest Service, Fort Collins.

[103] Schmid, J.M. and Frye, R.H. (1977) Spruce Beetle in the Rocky Mountains. General Technical Report RM-49, USDA Forest Service, Fort Collins.

[104] Morris, J.L., Cottrell, S., Fettig, C.J., DeRose, R.J., Mattor, K.M., Carter, V.A., Clear, J., Clement, J., Hansen, W.D., Hicke, J.A., Higuera, P.E., Seddon, A.W.R., Seppä, H., Sheriff, R.L., Stednik. J.D. and Seybold, S.J. (2018) Bark Beetles as Agents in Social-Ecological Systems. Frontiers in Ecology and the Environment, 16, S34-S43. https://doi.org/10.1002/fee.1754

[105] Neuvonen, S., Ruohomäki, K., Bylund, H. and Kaitaniemi, P. (2001) Insect Herbivores and Herbivory Effects on Mountain Birch Dynamics. In: Wielgolaski, F.E., Ed., Nordic Mountain Birch Ecosystems, CRC Press, Boca Raton, 207-222.

[106] Nuorteva, P. (1963) The Influence of Oporinia autumnata (Bkh.) (Lep., Geometridae) on the Timberline in Subarctic Conditions. Annales Entomologici Fennici, 29, 270-277.

[107] Holtmeier, F.-K., Broll, G., Müterthies, A. and Anschlag, K. (2003) Regeneration of Trees in the Treeline Ecotone: Northern Finnish Lapland. Fennia, 181, 103-128

[108] Holtmeier, F.-K. and Broll, G. (2006) Radiocarbon-Dated Peat and Wood Remains from the Finnish Subarctic: Evidence of Treeline and Landscape History. The Holocene, 16, 743-751. https://doi.org/10.1191/0959683606hl968rp

[109] Jepsen, J.U., Hagen, S.B., Ims, R.A. and Yoccoz, N.G. (2008) Climate Change and Outbreaks of the Geometrids Operophtera brumata and Epirrita autumnata in Subarctic Birch Forest: Evidence of a Recent Outbreak Range Expansion. Journal of Animal Ecology, 77, 257-264. https://doi.org/10.1111/j.1365-2656.2007.01339.x

[110] Baltensweiler, W., Benz, G., Bovey, P. and Dellucci, V. (1977) Dynamics of Larch-Bud Moth Population. Annual Review of Entomology, 22, 79-100. https://doi.org/10.1146/annurev.en.22.010177.000455

[111] Nägeli, W. (1969) Waldgrenze und Kampfzone in den Alpen. Hespa Mitteilungen, 19, 1-44.

[112] Schweingruber, F.H. (1979) Auswirkungen des Lärchenwicklerbefalls auf die Jahrringstruktur der Lärche. Schweizerische Zeitschrift für Forstwesen, 130, 1071-1093.

[113] Weber, U. (1995) Jahrringe als Ausdruck von Insektengradationen in den schweizerischen Alpen und der Front Range, Colorado. Ph.D. Dissertation, Philosophisch-Naturwissenschaftliche Fakultät, Basel.

[114] Bezzola, D. (1989) Zur Verjüngung und Sprossbildung der Arve unter dem Einfluss des Lärchenwicklers. Schweizerische Zeitschrift für Forstwesen, 140, 305-312.

[115] Baltensweiler, W. and Rubli, D. (1984) Forstliche Aspekte der LärchenwicklerMassenvermehrungen im Oberengadin. Mitteilungen der Eidgenössischen Anstalt für das forstliche Versuchswesen, Zürich, 1-184.

[116] Holtmeier, F.-K. (2012) Impact of Wild Herbivorous Mammals and Birds on the Altitudinal and Northern Treeline Ecotones. Landscape Online, 30, 1-28. https://doi.org/10.3097/LO.201230 
[117] Aulitzky, H. (1963) Bioklima und Hochlagenaufforstung in der subalpinen Stufe der Inneralpen. Schweizerische Zeitschrift für Forstwesen, 114, 1-25.

[118] Heiniger, M. and Kanter, E. (1988) Shoot Dieback in Subalpine Reforestations in Switzerland. Mitteilungen der forstlichen Bundesversuchsanstalt Wien, 162, 67-71

[119] Senn, J. (1999) Tree Mortality Caused by Gremeniella abietina in a Subalpine Afforestation in the Central Alps and its Relationships with Duration of Snow Cover. Forest Pathology, 29, 65-74. https://doi.org/10.1046/j.1439-0329.1999.00131.x

[120] Holtmeier, F.-K. (2005) Relocation of Snow and Its Effects in the Treeline Ecotone-With Special Regard to the Rocky Mountains, the Alps and Northern Europe. Die Erde, 136, 343-373

[121] Hoff, R. and Hagle, S. (1990) Diseases of Whitebark Pine with Special Emphasis on White Blister Rust. Proceedings of a Symposium on Whitebark Pine Ecosystems: Ecology and Management of a High-Mountain Resource, Bozeman, 29-31 March 1989, General Technical Report INT 270, USDA Forest Service, Ogden, 179-190.

[122] Mattson, D.J. and Reinhart, D P. (1994) Bear Use of Whitebark Pine Seeds in North America. Proceedings of the International Workshop on Subalpine Stone Pines and Their Environment. The Status of Our Knowledge, St. Moritz, 5-11 September 1992, General Technical Report INT-GTA 309, USDA Forest Service, Ogden, 212-220.

[123] Mattson, D.J., Kendall, K.C. and Reinhart, D.P. (2001) Whitebark Pine, Grizzly Bears, and Squirrels. In: Tomback, D.F., Arno, S.F. and Keane, R.E., Eds., Whitebark Pine Communities-Ecology and Restoration, Island Press, Washington DC, 121-136.

[124] Keane, R.E. and Arno, S.F. (1993) Rapid Decline of Whitebark Pine in Western Montana: Evidence from 20-Year Measurements. Western Journal of Applied Forestry, 8, 44-47.

[125] Bockino, N.K. and Tinker, D.B. (2012) Interactions of Whitebark Pine Blister Rust and Mountain Pine Beetle in Whitebark Pine Ecosystems in the Southern Greater Yellowstone Area. Natural Areas Journal, 32, 31-40.

https://doi.org/10.3375/043.032.0105

[126] Kendall, K.C. and Arno, S.F. (1990) Whitebarke Pine-An Important but Endangered Wildlife Resource. Proceedings of a Symposium on Whitebark Pine Ecosystems. Ecology and Management of a High-Mountain Resource, Bozeman, 29-31 March 1989, General Technical Report INT 270, USDA Forest Service, Ogden, 264-273.

[127] Mattson, D.J. and Reinhart, D.P. (1997) Excavation of Red Squirrel Middens by Grizzly Bears in the Whitebark Pine Zone. Journal of Applied Ecology, 34, 926-940. https://doi.org/10.2307/2405283

[128] Resler, L.M. and Tomback, D.F. (2008) Blister Rust Prevalence in Krummholz Whitebark Pine: Implications for Treeline Dynamics, Northern Rocky Mountains, Montana, U.S.A. Arctic, Antarctic, and Alpine Research, 40, 161-170. https://doi.org/10.1657/1523-0430(06-116)[RESLER]2.0.CO;2

[129] Campbell, E.M. and Antos, J.A. (2000) Distribution and Severity of Whitebark Pine Rust and Mountain Pine Beetle on Whitebark Pine in British Columbia. Canadian Journal of Forest Research, 30, 1051-1059. https://doi.org/10.1139/x00-020

[130] Tomback, D.F. and Resler. L.M. (2008) Invasive Pathogens at Alpine Treeline: Consequences for Treeline Dynamics. Physical Geography, 28, 397-418.

[131] Tomback, D.F., Blakeslee, S.C., Wagner, A.C., Wunder, M.B., Resler, L.M., Pyatt, J.C. and Diaz, S. (2016) Whitebark Pine Facilitation at Treeline: Potential Interactions for Disruption by an Invasive Pathogen. Ecology and Evolution, 6, 5144-5157. 
https://doi.org/10.1002/ece3.2198

[132] Schönenberger, W., Frey, W. and Leuenberger, F. (1990) Ökologie und Technik der Aufforstung im Gebirge: Anregungen für die Praxis.

[133] Evans, R. (1995) Impacts of Reindeer Grazing on Soils and Vegetation in Finnmark. Report 2033/02-94, NORUT Informasjonsteknologi, Tromsø.

[134] Löffler, J. (2000) High Mountain Ecosystems and Landscape Degradation in Northern Norway. Mountain Research and Development, 20, 356-363. https://doi.org/10.1659/0276-4741(2000)020[0356:HMEALD]2.0.CO;2

[135] Käyhkö, J. and Pellikka, P (1994) Remote Sensing of the Impact of Reindeer Grazing on Vegetation in Northern Fennoscandia Using SPOT XS Data. Polar Research, 13, 115-124. https://doi.org/10.1111/j.1751-8369.1994.tb00442.x

[136] Wielgolaski, F.E., Karlsson, P.S., Neuvonen, S., Thannheiser, D., Tømmervik, H. and Gautestad, A.O. (2005) The Nordic Mountain Birch Ecosystem-Challenges to Sustainable Management. In: Wielgolaski, F.E., Ed., Plant Ecology, Herbivory, and Human Impact in Nordic Mountain Birch Forests, Springer, Berlin, 343-356. https://doi.org/10.1007/3-540-26595-3_25

[137] Kallio, P. and Lehtonen, J. (1975) On the Ecocatastrophe of Birch Forest Caused by Oporinia autumnata (Bkh.) and the Problem of Reforestation. In: Wielgolaski, F.E., Ed., Fennoscandian Tundra Ecosystems, Springer, Berlin, 174-180. https://doi.org/10.1007/978-3-642-66276-8_23

[138] Oksanen, L., Moen, J. and Helle, H. (1995) Timberline Patterns in Northernmost Fennoscandia. Acta Botanica Fennica, 153, 93-105.

[139] Helle, T. (2001) Mountain Birch and Reindeer Husbandry. In: Wielgolaski, F.E., Ed., Nordic Mountain Birch Ecosystems, CRC Press, Boca Raton, 279-291.

[140] Lempa, K., Neuvonen, S. and Tømmervik, H. (2005) Effects of Reindeer Grazing on Pastures-A Necessary Basis for Sustainable Reindeer Herding. In: Wielgolaski, F E., Karlsson, P.S., Neuvonen, S. and Thannheiser, D., Eds., Plant Ecology, Herbivory and Human Impact in Nordic Mountain Birch Forests, Springer, Berlin, 157-164. https://doi.org/10.1007/3-540-26595-3_11

[141] Aune, S., Hofgaard, A. and Söderström. L. (2011) Contrasting Climate- and Land-Use-Driven Tree Encroachment Patterns of Subarctic Tundra in Northern Norway and the Kola Peninsula. Canadian Journal of Forrest Research, 41, 437-449. https://doi.org/10.1139/X10-086

[142] Turunen, M., Soppela, P., Hinnunen, H., Sutinen, M.-L. and Martz, F. (2009) Does Climate Change Influence the Availability and Quality of Reindeer Forage Plants? Polar Biology, 32, 813-832. https://doi.org/10.1007/s00300-009-0609-2

[143] Stark, S., Väisänen, M., Ylänne, H., Julkunen-Tiitto, R. and Martz, F. (2015) Decreased Phenologic Defence in Dwarf Birch (Betula nana) after Warming in Subarctic Tundra. Polar Biology, 38, 1993-2005.

https://doi.org/10.1007/s00300-015-1758-0

[144] Arno, S.F. (1980) Forest Fire History in the Northern Rockies. Journal of Forestry, 78, 460-465.

[145] Burga, C.A (1988) Swiss Vegetation History during the Last 18000 Years. New Phytologist, 110, 581-662. https://doi.org/10.1111/j.1469-8137.1988.tb00298.x

[146] Burga, C.A. and Perret, R. (2001) Monitoring of Eastern and Southern Swiss Alpine Timberline Ecotones. In: Burga, C. and Kratochwil, A., Eds., Biomonitoring: General and Applied Aspects on Regional and Global Scale, Springer, Dordrecht, 179-194. https://doi.org/10.1007/978-94-015-9686-2_11 
[147] Carcaillet, A.L., Teodose, J.P., Theurillat, J.-P., Thinon, M., Vadi, G. and Talon, B. (2004) Past Uppermost Tree Limit in the Central European Alps (Switzerland) Based on Soils and Soil Charcoal. The Holocene, 14, 393-405. https://doi.org/10.1191/0959683604hl715rp

[148] Staffler, H., Nicolussi, K. and Patzelt, G. (2011) Postglaziale Waldgrenzentwicklung in den Westtiroler Zentralalpen. Gredleriana, 11, 93-114.

[149] Scheurer, T., Jenny, H., Kupper, P., Parolini, J.D. and Schläpfer, D. (2014) Die Landschaft und ihre Nutzung von der letzten Eiszeit bis zur Parkgründung. In: Baur, B. and Scheurer, T., Eds., Wissen Schaffen: 100 Jahre Forschung im Schweizerischen Nationalpark, Haupt, Bern, 61-82.

[150] Vincze, L., Orbán, I., Birks, H., Pal, I., Finsinger, W., Hubay, K., Marinova, E., Jakab, G., Braun, M., Biró, T., Töth, M., Danau, C., Ferencz, V. and Magyari, E.K. (2017) Holocene Treeline and Timberline Changes in the South Carpathians (Romania): Climatic and Anthropogenic Drivers on the Southern Slopes of the Retezat Mountains. The Holocene, 27, 1613-1630. https://doi.org/10.1177/0959683617702227

[151] Schwörer, C., Kaltenrieder, P., Glur, A., Berlinger, M., Elbert, J., Frei, S., Gilli, A., Hafner, A., Anselmetti, S., Grosjean, M. and Tinner, W. (2014) Holocene Climate, Fire and Vegetation Dynamics at the Treeline in the Northwestern Swiss Alps. Vegetation History and Archaeobotany, 23, 479-496. https://doi.org/10.1007/s00334-013-0411-5

[152] Pini, R., Ravazzi, C., Raiteri, L., Guerreschi, A., Castellano, L. and Comolli, R. (2017) From Pristine Forests to High-Altitude Pastures: An Ecological Approach to Prehistoric Human Impact on Vegetation and Landscape in the Western Italian Alps. Journal of Ecology, 105, 1580-1597. https://doi.org/10.1111/1365-2745.12767

[153] Cudlin, P., Klopčič, M., Tognetti, R., Mális, F., Alados, C.L., Bebi, P., Grunewald, K., Zhiyanski, M., Andonowski, V., La Porta, N., Bratanova-Doncheva, S., Kachannovo, E., Edwards-Jonášová, M., Ninot, J.M., Rigling, A., Hofgaard, A., Hlásny, T., Skalák, P. and Wielgololaski, F.E. (2017) Drivers of Treeline Shift in Different European Mountains. Climate Research, 73, 135-150. https://doi.org/10.3354/cr01465

[154] Vitali, A., Camarero, J.J., Garbarino, M., Piermattei, A. and Urbinati, C. (2017) Deconstruction of Human-Shaped Treelines: Microsite Topography and Distance from the Seed Source Control Pinus nigra Colonization of Treeless Areas in the Italian Apennines. Forest Ecology and Management, 406, 37-45.

https://doi.org/10.1016/j.foreco.2017.10.004

[155] Bebi, P., Seidel, R., Motta, R., Fuhr, M., Firm, D., Krumme, F., Conedera, M., Ginzler, C., Wohlgemuth, T. and Kulakowski, D. (2017) Changes of Forest Cover and Disturbance Regimes in the Mountain Forests of the Alps. Forest Ecology and Management, 388, 43-56. https://doi.org/10.1016/j.foreco.2016.10.028 